SUMMARY OF WATER-RESOURCES ACTIVITIES OF

THE U.S. GEOLOGICAL SURVEY IN

COLORADO--FISCAL YEAR 1989

Compiled by Patricia A. Griffith

U.S. GEOLOGICAL SURVEY

Open-File Report 89-588 
DEPARTMENT OF THE INTERIOR

MANUEL LUJAN, JR., Secretary

U.S. GEOLOGICAL SURVEY

Dallas L. Peck, Director

For additional information write to:

District Chief

U.S. Geological Survey Box 25046, Mail Stop 415

Federal Center

Denver, CO 80225-0046
Copies of this report can be purchased from:

U.S. Geological Survey Books and Open-file Reports Section Box 25425

Federal Center

Denver, CO 80225-0425 
Introduction-10 Page

Mission of the U.S. Geological Survey- 2

Mission of the Water Resources Division- 3

Cooperating agencies- 4

Collection of water-resources data- 6

Surface-water data- 7

Ground-water data-:- 8

Meteorological data- 8

Interpretive hydrologic investigations

C0-83-005 National Trends Network for monitoring atmospheric deposition- 9

c0-78-007 Statewide water-use inventory- 10

C0-77-097 Effects of sludge disposal on ground-water quality-.-.-.- 11

C0-80-131 Effects of energy-production emissions on Colorado lakes--- 12

C0-81-158 Regional aquifer system analysis of the Upper Colorado River Basin in Colorado- 13

C0-82-159 Comprehensive hydrologic quantity and quality model of the Arkansas River basin, Colorado-

C0-83-172 Assessment of water resources and related effects resulting from military training in the Pinon Canyon area, Colorado

C0-84-180 Evaluation of nonpoint source contamination of the Fountain Creek alluvial aquifer. 16

C0-84-184 An update of fluvial-sediment discharge to the oceans from the United States-1.

c0-84-187 Total sediment transport at reservoir sites in western Colorado--... 18

c0-85-193 Wetland, ground-water, and surface-water relations in a subalpine valley in Grand County, Colorado-..............

c0-85-196 Sediment-transport characteristics and their effects on aquatic life in the Fountain Creek basin above Widefield,

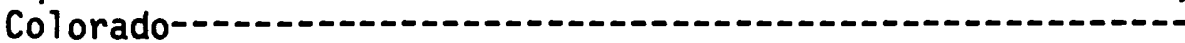

c0-85-197 Ground-water-quality effects of soil application of sewage sludge on farmland near Denver, Colorado-..-

C0-85-198 Comprehensive water-quality evaluation of Pueblo Reservoir, including the effects of potential contamination-.-.-

C0-85-199 Federal Series Reports Preparation Center-10

CO-85-200 Trends in water quality of Monument and Fountain Creeks, El Paso and Pueblo Counties, Colorado- 24

C0-86-217 Mechanisms of stream recovery from metal contamination----- 25

c0-86-218 Effects of current and projected wastewater effluents on Fountain and Monument Creeks, Colorado-..-

C0-86-222 Hydrology and geochemistry of reclaimed coal spoils in northwestern Colorado-

C0-87-223 Acidification of lakes along the Colorado Front Range--.-C0-87-224 Application of a geographic information system to determine the vulnerability of ground-water resources in the Greater Denver area--

C0-88-225 Hydraulic characteristics of confined clastic aquifers at Castle Pines, Colorado- 


\section{CONTENTS}

C0-88-227 Statistical analysis of water-quality data from selected

Page sites in the South Platte River basin and the Colorado

River basin in Colorado- 33

C0-88-229 National ground-water atlas-_- 34

C0-88-230 Irrigation-drainage field-screening study of the middle Arkansas River, Colorado and Kansas- 35

C0-88-231 Irrigation-drainage reconnaissance of the Gunnison River and Sweitzer Lake, west-central Colorado-_ 36

C0-88-232 Water-quality evaluation of the Arkansas River basin--.--- 38

CO-88-233 High Plains water-level network- 39

C0-89-234 Probability analysis of daily floodflows into Pueblo Reservoir during April and May-ar 40

C0-89-235 National Water Summary Report Preparation Center---.-- 41 C0-89-236 Irrigation-drainage reconnaissance of the Pine River area, Southern Ute Reservation, southwestern Colorado-....- 42

c0-89-237 Pueblo Depot Activity ground-water monitoring- 43

C0-89-238 Conjunctive water use and canal-seepage losses in an extensive irrigation system, southeastern Colorado-..-- 44

C0-89-239 Evaluation of trends in water quality of the Widefield aquifer, southwestern El Paso County, Colorado-.... 46

C0-89-240 Hillslope hydrology and sediment production at reclaimed surface-coal mines, northwestern Colorado-_. 47

Availability of Colorado District reports 49

Reports published or released during fiscal years 1987, 1988, and 1989--- 51

Water-resources data reports- 51

Water-resources interpretive reports- 52

Depositories-.

Projects completed except for reports during fiscal year 1989-1... 58

\section{PLATE}

Plate 1. Map showing location of water-resources data-collection stations in Colorado--fiscal year 1989-.-.-. [in pocket]

\section{TABLE}

Table 1. Water-resources data-collection stations in operation during 


\title{
SUMMARY OF WATER-RESOURCES ACTIVITIES \\ OF THE U.S. GEOLOGICAL SURVEY IN \\ COLORADO--FISCAL YEAR 1989
}

\section{INTRODUCTION}

Water-resources activities of the U.S. Geological Survey in Colorado consist of collecting water-resources data and conducting interpretive hydrologic investigations. The water-resources data and the results of the investigations are published or released by either the U.S. Geological Survey or by cooperating agencies. Water-resources investigations in Colorado for the 1989 fiscal year (October 1, 1988, to September 30, 1989) are described in this report.

The U.S. Geological Survey's investigations of the water resources of Colorado are under the direction of C.A. (Jerry) Pascale, District Chief. The Colorado District office is located on the second floor of Building 53, Denver Federal Center, Denver, Colorado. The Colorado District has three Subdistrict offices, the Lakewood Subdistrict office in Denver, the Western Slope Subdistrict office in Grand Junction, and the Pueblo Subdistrict office in Pueblo, and two field offices, in Durango and Meeker. Requests for information should be addressed as follows:

\author{
C.A. (Jerry) Pascale, District Chief \\ U.S. Geological Survey \\ Water Resources Division \\ Box 25046, Mail Stop 415 \\ Denver Federal Center \\ Denver, CO 80225-0046 \\ Telephone: (303) 236-4882
}

D.J. Lystrom

Associate District Chief and

Chief, Hydrologic Studies Section

U.S. Geological Survey

Water Resources Division

Box 25046, Mail Stop 415

Denver Federal Center

Denver, CO 80225-0046

Telephone: (303) 236-4882

Sherman R. Ellis

Chief, Environmental

Assessment Unit

U.S. Geological Survey

Water Resources Division

Box 25046, Mail Stop 415

Denver Federal Center

Denver, CO 80225-0046

Telephone: (303) 236-4886
Kathleen R. Wilke

Assistant District Chief and Chief, Hydrologic Surveillance Section

U.S. Geological Survey

Water Resources Division

Box 25046, Mail Stop 415

Denver Federal Center

Denver, C0 80225-0046

Telephone: (303) 236-4882

Stanley G. Robson

Chief, Hydrogeologic Unit

U.S. Geological Survey

Water Resources Division

Box 25046, Mail Stop 415

Denver Federal Center

Denver, CO 80225-0046

Telephone: (303) 236-4886 
R.F. Middelburg, Jr.

Chief, Computer Services Section

U.S. Geological Survey

Water Resources Division

Box 25046, Mail Stop 415

Denver Federal Center

Denver, CO 80225-0046

Telephone: (303) 236-4882

Doug Cain, Subdistrict Chief

U.S. Geological Survey

Water Resources Division

P. 0. Box 1524

Pueblo, CO 81002

Telephone: (719) 544-7155

Richard A. Herbert

Subdistrict Chief

U.S. Geological Survey

Water Resources Division

Box 25046, Mail Stop 423

Denver Federal Center

Denver, CO 80225-0046

Telephone: (303) 236-9404
Linda J. Britton

Chief, Publications Section

U.S. Geological Survey

Water Resources Division

Box 25046, Mail Stop 415

Denver Federal Center

Denver, CO 80225-0046

Telephone: (303) 236-4895

Dannie L. Collins, Subdistrict Chief

U.S. Geological Survey

Water Resources Division

P.0. Box 2027

Grand Junction, CO 81502

Telephone: (303) 245-5257

Robert L. Tobin

Field Office Chief

U.S. Geological Survey

Water Resources Division

P. 0. Box 810

Meeker, CO 81641

Telephone: (303) 878-5086

James D. Bennett, Field Office Chief

U.S. Geological Survey

Water Resources Division

P. 0. Box 3367

Durango, CO' 81302

Telephone: (303) 385-1320

\section{MISSION OF THE U.S. GEOLOGICAL SURVEY}

The U.S. Geological Survey was established by an act of Congress on March 3, 1879, to answer the need for a permanent government agency at the Federal level to conduct, on a continuing, systematic, and scientific basis, investigations of the "geological structure, mineral resources, and products of the national domain." Although a number of laws and executive orders have expanded and modified the scope of the Survey's responsibilities during its 110-year history, the Survey has remained principally a scientific and technical investigation agency as contrasted with a developmental or regulatory one. Today the Survey is mandated to assess onshore and offshore energy and mineral resources; to provide information for society to mitigate the impact of floods, earthquakes, landslides, volcanoes, and droughts; to monitor the Nation's ground- and surface-water supplies; to study the impact of man on the Nation's water resources; and to provide mapped information on the Nation's landscape and land use. The Survey is the principal source of scientific and technical expertise in the earth sciences within the Department of the Interior and the Federal Government. The Survey's activities span a wide range of earth-science research and services in the fields of geology, hydrology, and cartography and represent the continuing pursuit of the longstanding scientific missions of the Survey. ${ }^{1}$

1Source: Adapted (and updated December 1984) from U.S. Geological Survey Yearbook for Fiscal Year 1983. 


\section{MISSION OF THE WATER RESOURCES DIVISION}

The mission of the Water Resources Division, which supports the mission of the Geological Survey and the U.S. Department of the Interior, is to develop and disseminate scientific knowledge and understanding of the Nation's water resources. The activities carried out by the Water Resources Division fall into three broad categories: (1) resource assessment; (2) research; and (3) coordinating the activities and cataloging the products of numerous other entities involved in water research, data acquisition, or information transfer.

Resource Assessment. Resource assessment consists of:

- Collecting data on the quantity, quality, and use of surface water (rivers, streams, lakes, reservoirs, estuaries, and glaciers); the quantity, quality, and use of ground water (including water in the unsaturated zone); and the quality of precipitation.

- $\quad$ Storing and disseminating these data.

- Interpreting these data and publishing the results of these interpretations. This involves the inference of hydrologic causes, effects, and probabilities; and the extension, over space and time, of information contained directly in the data.

- Developing and applying new methods of hydrologic data collection, analysis, and interpretation.

- Conducting areally focused interpretive investigations and appraisals at national, regional, State, or local scales. These include characterizations of ground and surface waters, and of precipitation chemistry, evaluation of natural hydrologic hazards, and studies of other water-related topics. Frequently these investigations involve the development, testing, and application of mathematical models capable of predicting the hydrologic consequences of management actions, development plans, or natural phenomena. These investigations are carried out through specific Federal programs or in cooperation with State and local governments or other Federal agencies. Results are published in technical journals or in State, local, USGS, or other Federal agency publications.

- Reporting to the Nation, on a regular basis, on the overall status of the water resource, and on hydrologic events and water-resource issues.

Research. The Division conducts research in a wide variety of scientific disciplines--geochemistry, ecology, geomorphology and sediment transport, water chemistry, ground-water hydrology, and surface-water hydrology-particularly as these disciplines relate to the quantity, flow, and quality of surface water and ground water and to other aspects of the hydrologic cycle. The research is intended to:

- Improve the overall understanding of the pathways, rates of movement, chemical processes, and biological processes in the hydrologic cycle. 
- Improve the overall understanding of the hydraulic, chemical, and biological factors, both natural and anthropogenic, which affect the resource.

-

Provide new strategies of data collection, analysis, and interpretation, in the light of new knowledge and evoiving scientific capabilities.

- Improve methods of predicting the response of hydrologic systems to stresses, whether hydraulic or chemical, and whether of natural or human origin.

Coordinating the Activities and Cataloging the Products of Other Entities Involved in Water Research, Data Acquisition, or Information Transfer.

This function has four major components:

- The coordination of water-data acquisition activities of Federal agencies (as mandated by OMB Circular A-67).

- The acquisition of water-use data and development of State and national water-use data bases in cooperation with State governments.

- The operation of Water Information Exchanges and Centers which provide all interested parties with indexing and access to many sources of water data and information.

○

The administration of extramural water-resources research, technology, development, academic training, and information-transfer programs mandated by the Water Resources Research Act of 1984 (Public Law 98-242). The Act mandates research oriented to the environmental values associated with the resource. The research promoted by the Act involves many disciplines and activities other than those required in the assessment, research, and coordinating functions of the Water Resources Division. 2

\section{COOPERATING AGENCIES}

In Colorado, some of the water-resources data-collection activities and interpretive hydrologic investigations are conducted in cooperation with Federal, State, and local agencies. Those agencies cooperating with the U.S. Geological Survey during fiscal year 1989 are as follows:

Arkansas River Compact Administration

Bent County Board of County Commissioners

Boulder County Public Works Department

Castle Pines Metropolitan District

Castle Pines North Metropolitan District

Centennial Water and Sanitation District

Cherokee Water and Sanitation District

City and County of Denver, Board of Water Commissioners

2Source: Mission statement by the Chief Hydrologist, September 28, 1984. 
City of Arvada

City of Aspen

City of Aurora

City of Boulder

City of Colorado Springs, Department of Utilities

City of Colorado Springs, Office of Community Development

City of Englewood

City of Fort Collins

City of Glendale

City of Glenwood Springs

City of Longmont

City of Loveland

City of Steamboat Springs

City of Thornton

City of Westminster

Colorado Department of Health

Colorado Department of Natural Resources

Division of Mined Land Reclamation

Division of Water Resources, Office of the State Engineer

Colorado River Water Conservation District

Colorado Water Conservation Board

Delta County Board of County Commissioners

Denver Regional Council of Governments

Evergreen Metropolitan District

Fountain Valley Authority

Garfield County Board of County Commissioners

Lower Fountain Water Quality Management Association

Metropolitan Denver Sewage Disposal District No. 1

Moffat County Board of County Commissioners

Northern Colorado Water Conservancy District

Pikes Peak Area Council of Governments

Pitkin County Board of County Commissioners

Pueblo Board of Water Works

Pueblo County Department of Public Safety and Operations

Pueblo County Board of County Commissioners

Pueblo West Metropolitan District

Rio Blanco County Board of County Commissioners

Rio Grande Water Conservation District

Routt County Board of County Commissioners

St. Charles Mesa Water District

Southeastern Colorado Water Conservancy District

Southern Ute Indian Tribe

Southwestern Colorado Water Conservancy District

Town of Breckenridge

Town of Castle Rock

Trinchera Water Conservancy District

Uncompahgre Valley Water Users Association

Upper Arkansas Council of Governments

Upper Arkansas River Water Conservancy District

Upper Eagle Regional Water Authority

Upper Eagle Valley Water and Sanitation District

Upper Yampa Water Conservancy District

Urban Drainage and Flood Control District 
U.S. Department of Defense

Department of the Air Force

Air Force Academy

Office of Environmental and Health Laboratories

Department of the Army

Corps of Engineers

Albuquerque District

Fort Carson

Omaha District

Pueblo Depot Activity

U.S. Department of the Interior

Bureau of Land Management

Bureau of Reclamation

Fish and Wildlife Service

National Park Service

Office of Surface Mining Reclamation and Enforcement

U.S. Environmental Protection Agency

- Ute Mountain Ute Indian Tribe

Vail Valley Consolidated Water District

Water Users No. 1

Yellow Jacket Water Conservancy District

\section{COLLECTION OF WATER-RESOURCES DATA}

Hydrologic-data stations are maintained at selected locations throughout Colorado and constitute a water-resources-data network for obtaining records on streamflow stage and discharge, lake storage and reservoir, ground-water levels, well and spring discharge, the quality of surface and ground water, and meteorological data (table 1). Every year some new stations are added and other stations are terminated; thus, the U.S. Geological Survey has a current and a historical file of hydrologic data. Most water-resources data are stored in the U.S. Geological Survey's NWIS (National Water Information System) data base and are available on request to water planners and others involved in making decisions affecting Colorado's water resources. These data can be retrieved in machine-readable form or in the form of computer-printed tables, statistical summaries, and digital plots. Local assistance in the acquisition of services or products from NWIS can be obtained by contacting the District Chief, Denver, Colo. 
Table 1.--Water-resources data-collection stations in operation during fiscal year 1989, by station classification

[The number and type of stations located in each county are shown on plate 1 (in pocket)]

Streamflow:

Continuous (daily) record

328

Seasonal (daily) record

Peakflow, crest-stage record

39

Real-time stage and discharge

Lakes and reservoirs:

Stage and contents

Real-time stage and contents

Water quality:

Periodic chemical quality

94

Daily quality monitoring

Ground water:

Periodic water levels $\quad 1,450$

Daily water levels $\quad 14$

Chemical quality $\quad 65$

Meteorological:

Daily precipitation or air temperature or both 52

Periodic precipitation quality 1

Real-time precipitation or air temperature or both 25

\section{Surface-Water Data}

Surface-water stage (water level), discharge (streamflow), and waterquality data are collected for general hydrologic purposes, such as assessment of water resources, areal analysis, determination of long-term trends, research and special studies, or for management and operational purposes. Data-collection platforms (DCP's), used for the transmission of satellitetelemetered river-stage information, have been installed at 34 sites throughout the State. Satellite-telemetry acquisition of the information is essential to many agencies for operating reservoirs, predicting river stage and flood conditions, and optimizing the use of water resources. DCP information is transmitted to the GOES (Geostationary Operational Environmental Satellite) and received at the U.S. Geological Survey DRGS (Direct Readout Ground Station) located in Denver, where it is processed and made available to other agencies.

Periodic water-quality data (major ions, nutrients, trace metals, pesticides, or radiochemicals) are obtained at 94 of the surface-water stations listed in table 1 . Seven of these stations are part of a U.S. Geological Survey nationwide network known as NASQAN (National Stream Quality Accounting Network) and two of these stations are part of the nationwide Benchmark network that provides data used in the evaluation of trends in stream quality. 
Daily water-quality monitoring for water temperature, $\mathrm{pH}$, dissolved oxygen, specific conductance, or turbidity is being conducted at 35 sites. Automatic instruments measure the parameters of interest hourly during the day, enabling the information to be summarized for the day, such as the daily maximum, minimum, and mean.

Information from water-quality stations is used to monitor the quality of surface water in Colorado. The frequency of sample collection can vary from daily for some of the physical data to annually for pesticide or radiochemical data.

A variety of water-quality data is collected at miscellaneous sites that are part of interpretive hydrologic studies. This information also is available from the U.S. Geological Survey files.

\section{Ground-Water Data}

Water levels in wells are key characteristics for monitoring ground-water trends; however, they must be integrated with other observations and groundwater investigations to have the most relevance and usefulness. A network of 650 observation wells is maintained in eastern Colorado for monitoring fluctuations in water levels, in cooperation with the Colorado Division of Water Resources and various eastern-slope water-conservancy districts and watermanagement districts. Other wells, known as "project wells", are used for specific (generally short-term) investigations; although these wells are not part of the observation-well networks, data obtained from them also are available.

Water-quality data are not collected routinely from wells in the statewide networks. However, a variety of water-quality data were collected at 80 wells during 1989 for interpretive hydrologic investigations. These data are available from the files of the U.S. Geological Survey.

\section{Meteorological Data}

Daily precipitation quantity or air temperature or both are collected and published at 25 monitoring stations in Colorado. One station, located in Bent County, is part of the nationwide NTN (National Trends Network) program to monitor long-term precipitation-quality changes. Precipitation quantity or air temperature or both are measured and satellite-telemetered to the U.S. Geological Survey DRGS from 34 stations. Information from the precipitation stations is available to users on request.

\section{INTERPRETIVE HYDROLOGIC INVESTIGATIONS}

Thirty-five interpretive hydrologic investigations are being conducted during fiscal year 1989 in cooperation with 29 Federal, State, and local agencies. Hydrologic investigations are being conducted that will provide information needed to answer hydrologic questions specific to the State's four major river basins (Missouri, Arkansas, Rio Grande, and Colorado), as well as questions addressing statewide, multistate, and nationwide hydrologic problems. A summary of each investigation, including problem, objectives, approach, progress, and plans follows. 
PROJECT TITLE:

National Trends Network for Monitoring Atmospheric Deposition

PROJECT NUMBER:

C0-83-005

STUDY LOCATION:

Bent County, Colorado

COOPERATING AGENCY: None--U.S. Geological Survey funds

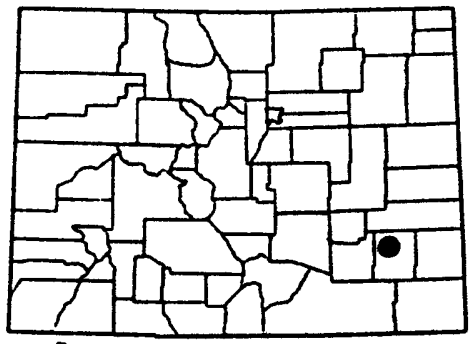

PROJECT CHIEF AND OFFICE:

Ronnie D. Steger, Subdistrict Office, Pueblo

PROJECT DURATION: October 1983 to September 1989

PROBLEM: Great variability exists nationwide in precipitation quality and quantity and their potential environmental impacts.

OBJECTIVES: To monitor precipitation volume and chemistry as part of the National Trends Network (NTN). To relate precipitation chemistry and volume to concurrent discharge and stream chemistry.

APPROACH: Maintain and operate a monitoring station that is part of a nationwide network established to provide concentrations, loads, and time trends of chemical constituents in precipitation and stream water.

PROGRESS: Data collection continued on a weekly basis at one rain gage, with sampling as required.

PLANS FOR FY 1989: Weekly visitation of the site and sampling as required will be continued. 
PROJECT TITLE: $\quad$ Statewide Water-Use Inventory

PROJECT NUMBER: $\quad$ CO-78-007

STUDY LOCATION: $\quad$ Statewide

COOPERATING AGENCIES: City and County of Denver, Board of Water Commissioners;

Colorado Department of Natural Resources, Division of Water Resources, Office of the State Engineer;

Colorado River Water Conservation District

PROJECT CHIEF AND OFFICE:

David L. Litke, District Office, Denver

PROJECT DURATION: October 1977 to September 1989

PROBLEM: Water-use data in Colorado are not complete and detailed enough for planning purposes and implementation of a State water plan. Sources of water supplies, water use, and the volume of water consumed or available for multiple use require documentation so that State and local managers and planners may be better informed to make decisions for development of the State's water resources.

OBJECTIVES: Maintain a computerized water-use data base that can be accessed by a variety of users. Develop methods for more complete and accurate estimation of water use.

APPROACH: Obtain water-use data by contacting users, accessing pre-existing data bases, and developing estimation techniques when necessary.

PROGRESS: Water-use data collected for 1985 were summarized in two reports: the Colorado State section of the 1987 National Water Summary (in press), and Water-Resources Investigations Report 88-4101 "Estimated use of water in Colorado, 1985." Two papers describing water-use estimation techniques were published in the Proceedings of the Symposium on Water-Use Data for Water-Resource Management, held in Tucson, Ariz., August 28-31, 1988. A poster depicting water use in Colorado also is available.

PLANS FOR FY 89: Methods to estimate irrigation water use, using remote sensing techniques and geographic information system technology, will be documented. A prototype GIS-based irrigation water-use data base will be developed. Municipal water-use patterns will be statistically analyzed, using data collected by the Denver Water Department. 
PROJECT TITLE:

PROJECT NUMBER:

STUDY LOCATION:

COOPERATING AGENCY:
Effects of Sludge Disposal on Ground-Water Quality

C0-77-097

Arapahoe County

Metropolitan Denver Sewage Disposal District No. 1

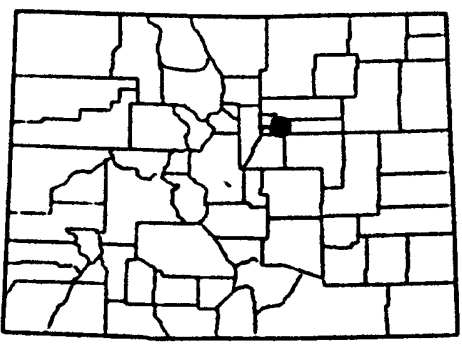

PROJECT CHIEF AND OFFICE:

Neville G. Gaggiani, Subdistrict Office, Denver

PROJECT DURATION: May 1977 to September 1989

PROBLEM: In 1983, nitrate-nitrogen concentrations in the hundreds of milligrams per liter were measured in the alluvial aquifer within the Lowry sewage-sludge land-disposal site located in Arapahoe County, Colorado. Metropolitan Denver Sewage Disposal District No. 1 has been operating the site for more than 10 years. Although the large concentrations seem to be confined to the site, concern exists that the contamination could spread and affect ground-water quality adjacent to the site.

OBJECTIVES: Determine the location of, depth to, and areal extent of alluvial and bedrock aquifers beneath the sludge-disposal site and adjacent area. Determine the direction of ground-water flow and the quality of ground water.

APPROACH: Expand the present ground-water monitoring network within an approximate 28-square-mile area around the sludge-disposal site. Using observation wells, obtain water-level measurements and samples for waterquality analysis. Construct potentiometric-surface maps of the alluvial and bedrock aquifers to aid in determining ground-water flow paths. Solute-transport potential will be evaluated, based on estimates of aquifer hydraulic properties.

PROGRESS: The final report is written and is in review. Out of 28 wells sampled, 13 wells contained water with nitrogen concentrate ranging from 0.01 to $1,060 \mathrm{mg} / \mathrm{L}$. Trace metals in 1 arge concentrations have not been detected in the wells but are present in concentrations ranging from $<10$ to $140 \mu \mathrm{g} / \mathrm{g}$ lead, <1 to $10 \mu \mathrm{g} / \mathrm{g}$ cadmium, 1 to $5 \mu \mathrm{g} / \mathrm{g}$ arsenic, and 0.01 to $3.8 \mu \mathrm{g} / \mathrm{g}$ mercury in the soil where sludge was applied.

PLANS FOR FY 89: The project will be completed. A new proposal will be written to address a revised monitoring program and data evaluation. 
PROJECT TITLE: $\quad$ Effects of Energy-Production Emissions on Colorado Lakes

PROJECT NUMBER:

$\mathrm{C} 0-80-131$

STUDY LOCATION:

Rio Blanco, Garfield, Mesa, and Delta Counties in northwestern Colorado

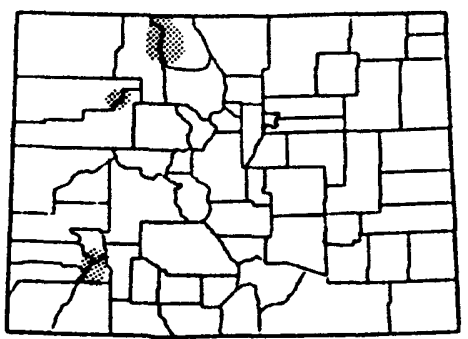

COOPERATING AGENCIES: Colorado Department of Health, Delta County Board of County Commissioners,

U.S. Environmental Protection Agency, and

U.S. Geological Survey

PROJECT CHIEF AND OFFICE:

John T. Turk, District Office, Denver

PROJECT DURATION: November 1979 to September 1989

PROBLEM: Current and proposed production of energy in Colorado and surrounding States will release acidic gases and other constituents that can affect the chemistry of precipitation and of poorly buffered lakes and streams. The water resources of the Flat Tops, Mt. Zirkel, and Weminuche Wilderness Areas in western Colorado are located downwind from areas of possible oil-shale development and coal-burning powerplants. The unreactive bedrock of the area, combined with the orographic effect on precipitation, may cause the area to be particularly susceptible to adverse effects of energy production. Data on precipitation and lake quality do not exist to define predevelopment conditions or relative sensitivity of waters to input of additional chemical constituents.

OBJECTIVES: Delineate the areas in Colorado most susceptible to the influence of acid rain. Determine within susceptible areas the lakes with the least buffering capacity and the smallest nutrient-loading rate. Select lakes representative of other lakes within the susceptible areas for more detailed study. Determine baseline chemical quality of precipitation.

APPROACH: Select areas most susceptible to acidification based on the following: downwind location from acidic-gas sources, unreactive bedrock geology, and large snowpack accumulation. Measure relative buffering capacity of the lakes by alkalinity-titration curves. Install and operate precipitation gages and weather stations to collect samples for analysis of wet- and dry-deposition quality and data on wind direction and speed.

PROGRESS: Samples have been collected and analyzed to determine whether trends exist in sulfate within atmospheric deposition or in Ned Wilson Lake-Flat Tops Wilderness Area, Colorado.

PLANS FOR FY 89: Monitoring of lakes and wetfall will continue to establish whether trends exist in other areas of western Colorado. 
PROJECT TITLE: $\quad$ Regional Aquifer System Analysis of the Upper Colorado River Basin in Colorado

PROJECT NUMBER: $\quad$ CO-81-158

STUDY LOCATION: $\quad$ The Upper Colorado River Basin in western Colorado

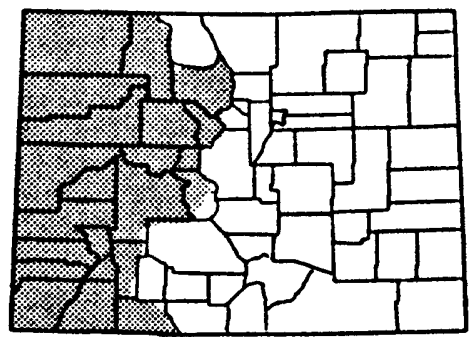

COOPERATING AGENCY: None--U.S. Geological Survey funds only

PROJECT CHIEF AND

OFFICE:

Emanuel Weiss, District Office, Denver

PROJECT DURATION: JuTy 1981 to September 1989

PROBLEM: Water demands are increasing in the Upper Colorado River Basin. Ground-water reservoirs may contain large water supplies, but not all water supplies have been investigated. Effective water management cannot proceed until quantity and quality of available water supplies have been appraised.

OBJECTIVES: Locate major aquifer systems, estimate the volume of ground water in storage, determine the quality of available ground water, and estimate the hydrologic impacts of major withdrawals and injection.

APPROACH: Compile hydrologic and geochemical data from existing well logs and onsite inventory of wells and springs. Prepare and use simulation models to estimate the effects of withdrawals from, and injection into, various aquifer systems.

PROGRESS: The modeling summary professional paper progressed through in-house, technical, and editorial review. The geohydrology of Mesozoic rocks professional paper was approved by the Director. The geohydrology of Tertiary rocks and the geohydrology of Paleozoic rocks professional papers were processed through colleague review. The summary professional paper was begun.

PLANS FOR FY 89: All required professional papers will be submitted to the Director for approval. 
PROJECT TITLE: $\quad$ Comprehensive Hydrologic Quantity and Quality Model of the Arkansas River basin, Colorado

PROJECT NUMBER: $\quad$ CO-82-159

STUDY LOCATION: $\quad$ The Arkansas River basin of southeastern Colorado

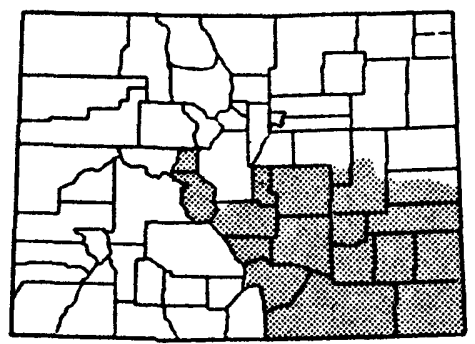

COOPERATING AGENCY: Southeastern Colorado Water Conservancy District

PROJECT CHIEF AND OFFICE:

Doug Cain, Subdistrict Office, Pueblo

PROJECT DURATION: October 1981 to September 1990

PROBLEM: Major changes in water use and resultant water quality in the Arkansas River basin are affecting all water users. The current overappropriation of surface-water supplies has led to a complex water-supply system of transmountain diversions, reservoir storage, and development of the alluvial aquifer. Currently, no consistent, comprehensive means exist to assess the possible water-quantity and water-quality effects of the many possible changes in the competing water uses.

OBJECTIVE: Construct and document a model capable of assessing the basinwide quantity and quality effects resulting from changes in water management and water use. This model would be an interactive, planning-type, stream-network model to simulate the effect of the adjacent alluvial aquifer, simulate water quality for conservative constituents, and include the legal-priority system of Colorado water law.

APPROACH: Develop the model from existing stream-network and stream-aquifer models. Develop stream-aquifer response functions, precipitation-runoff relations, water-quality discharge relations, and irrigation applicationrecharge factors for entry into the model. Calibrate the model, demonstrate examples of the model's predictive capabilities, and describe them in a report.

PROGRESS: Five reports planned to document results of the modeling effort have been published: "Selected hydrographs and statistical analyses characterizing the water resources of the Arkansas River basin, Colorado," by Alan W. Burns; "Descriptions of water-systems operations in the Arkansas River basin, Colorado," by P.O. Abbott; "Relations of specific conductance to streamflow and selected water-quality characteristics of the Arkansas River basin, Colorado," by Doug Cain; "Computer-program documentation of an interactive-accounting model to simulate streamflow, water quality, and water-supply operations in a river basin," by Alan W. Burns; and "Calibration and use of an interactive-accounting model to simulate the streamflow, dissolved solids, and water-supply operations in the Arkansas River basin, Colorado," by Alan $W$. Burns. The datamanagement package for the model was upgraded and the data base was updated to 1987.

PLANS FOR FY 89: The calibration report will be distributed. The model data base will be updated to 1988 . 
PROJECT TITLE: Assessment of Water Resources and Related Effects Resulting from Military Training in the Pinon Canyon Area, Colorado

PROJECT NUMBER: $\quad$ CO-83-172

STUDY LOCATION: $\quad$ Southeastern Colorado, including tributaries of the Purgatoire and

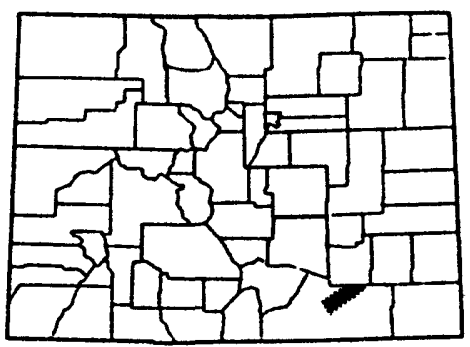
Apishapa Rivers in Las Animas County

COOPERATING AGENCY: U.S. Department of the Army, Fort Carson

PROJECT CHIEF AND OFFICE:

Paul B. von Guerard, Subdistrict Office, Pueblo

PROJECT DURATION: October 1982 to September 1989

PROBLEM: A 400-square-mile area will be acquired in the Pinon Canyon area by the U.S. Army and used for military training, beginning in 1985. Conversion of land use from grazing may alter streamflow and water quality. These changes could not be quantified in the environmental impact statement for the acquisition, but they are a concern to downstream water users in Colorado and Kansas. The Authorizing Act for the acquisition directs the Army to establish a system of hydrologic monitoring to collect baseline data and record changes in the quantity and quality of water flowing from the land acquired.

OBJECTIVES: Assess the quantity and quality of both surface- and ground-water resources in the area. Determine the effect of military training on the water resources of the area.

APPROACH: Monitor surface-water flow and specific conductance at 10 streamflow-gaging stations and collect sediment samples by using automatic samplers at seven stations. Collect water-quality samples of base flow and storm runoff at all stations. Determine current (1983-84) reservoir capacity in 49 small reservoirs; probe 29 of these reservoirs to determine historical sediment content and resurvey all reservoirs following military training. Inventory existing wells, measure water levels monthly in 10 wells, and collect samples of water from 50 wells. Intensity instrument one drainage basin on the site and use information to calibrate rainfall-runoff model.

PROGRESS: The report entitled "Hydrology of the Pinon Canyon Maneuver site, Las Animas County, Colorado" was published. The first draft of a report describing the effects of military land use on the hydrology of the Maneuver Site was prepared. Collection of hydrologic records continued at 10 surface-water stations, 23 precipitation gages, and 10 wells.

PLANS FOR FY 89: Collection of hydrologic records will continue at all stations. A soil-moisture data-collection network using time-domain reflectrometry will be installed and operated at several disturbed and undisturbed sites in the area and in the intensively instrumented basin to provide additional information for calibration of the rainfall-runoff model. The effects of military maneuvers on soil bulk density will be determined. 
PROJECT TITLE:

PROJECT NUMBER:

STUDY LOCATION:
Evaluation of Nonpoint Source Contamination of the Fountain Creek Alluvial Aquifer

C0-84- 180

El Paso and Pueblo Counties, Colorado

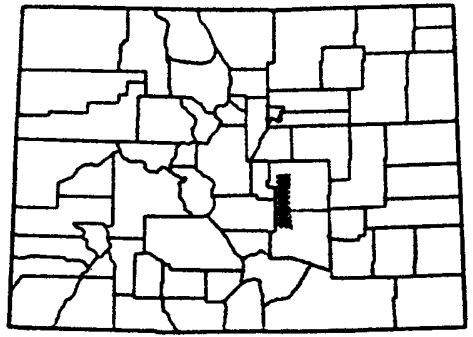

COOPERATING AGENCY: None--U.S. Geological Survey funds only

PROJECT CHIEF AND OFFICE

Daniel T. Chafin, Subdistrict Office, Pueblo

PROJECT DURATION: April 1984 to September 1990

PROBLEM: Stream-aquifer systems are among the most important sources of ground-water supply for municipal and agricultural uses in the semiarid West. Concurrently, the streams that are part of these systems often are used heavily for disposal of municipal, industrial, and agricultural waste water, resulting in a large potential for ground-water contamination. Currently, little is known about the concentrations, distribution, sources, and movement of hazardous substances in stream-aquifer systems. These factors complicate attempts to determine the effects of land use on ground-water quality.

OBJECTIVES: Determine the occurrence and distribution of organic substances and trace metals in the Fountain Creek stream-aquifer system. Determine if the occurrence or concentrations are related to land use or quality of recharge water. Determine the effects of season and aquifer depth on the water quality of each land-use category.

APPROACH: Assemble and evaluate existing data on water quality, well location and construction, land use, and waste discharge. Review literature on sampling methods for organics. Collect reconnaissance water-quality data from about 10 wells under each land use. Evaluate reconnaissance data for relation between water quality and land use. Define two separate areas that characterize urban and agricultural land uses. Randomly locate about 20 sites in each area and emplace a network of 20 shallow wells and 10 matched-pair deep wells in each area. Choose five surface-water sites for water-quality sampling. Sample well network in summer and winter and sample surface-water sites during three seasonally dependent events. Correlate surface-water data with ground-water data and statistically: compare ground-water data with respect to land use and seasonal and aquifer-depth differences.

PROGRESS: A report on the reconnaissance phase of the study was published as Water-Resources Investigations Report 86-4085. A network of 74 monitoring wells was installed during summer 1987, and samples for a broad range of organic and inorganic constituents were collected from all the wells and at five surface-water sites on Fountain Creek during summer 1988.

PLANS FOR FY 89: Approximately 40 additional water-quality samples will be collected from the Fountain Creek alluvial aquifer system during winter 1988-89. Data from the studies will be collated as they become available and put in computerized format for statistical and graphical analysis. Results will be interpreted and report preparation will begin. 
PROJECT TITLE: An Update of Fluvial-Sediment Discharge to the Oceans from the United States

PROJECT NUMBER: $\quad$ CO-84-184

STUDY LOCATION: Nationwide

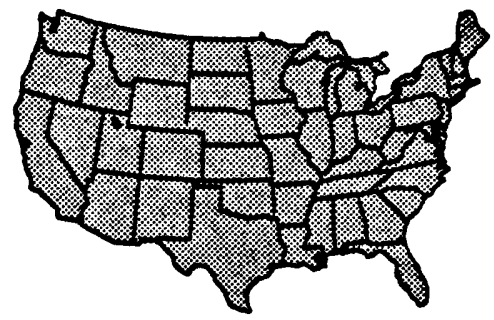

COOPERATING AGENCY: None--U.S. Geological Survey funds only

PROJECT CHIEF AND

OFFICE:

Randolph S. Parker, District Office, Denver

PROJECT DURATION: Aprit 1984 to September 1989

PROBLEM: Knowledge of the quantity of sediment transported by the various rivers of the United States is essential for the following: (1) Designing reservoirs to allow sufficient space to store sediment expected to accumulate in reservoirs; (2) predicting the fate of contaminants, such as pesticides, radionuclides, and toxic metals that can be adsorbed to the sediment particles; and (3) indicating regional and continental rates of erosion. A summary of transported sediment will be useful to the hydrologic community.

OBJECTIVE: Calculate sediment outflow to the oceans from the major sedimentproducing rivers of the United States. In addition, give examples of changes in sediment yields from man's activities upstream and examples of extreme events and their impact on sediment production.

APPROACH: Calculate sediment yields of major river basins in the United States from data contained in WATSTORE. Record examples from the literature of the impacts of man's modifications and of extreme events.

PROGRESS: Sediment budgets for the major rivers of the United States have been constructed. The natural variability that affects the mean sediment discharge has been examined in the lower Missouri River basin. Standard error of the mean increases on the main stem from Sioux City, Iowa, to Hermann, Mo. Calculations of sediment discharge in tributaries on this reach have greater standard errors than do calculations of similar data from main-stem stations.

PLANS FOR FY 89: Daily sediment stations will be used to provide a population of suspended-sediment data, and samples withdrawn from this population will be used to estimate the annual suspended-sediment discharge. This method will be used to estimate the error associated with load estimates from periodic samples. 
PROJECT TITLE:

PROJECT NUMBER:

STUDY LOCATION:

COOPERATING AGENCIES:

PROJECT CHIEF AND OFFICE:

PROJECT DURATION:
Total Sediment Transport at Reservoir Sites in Western Colorado

C0-84-187

Proposed reservoir sites, western Colorado

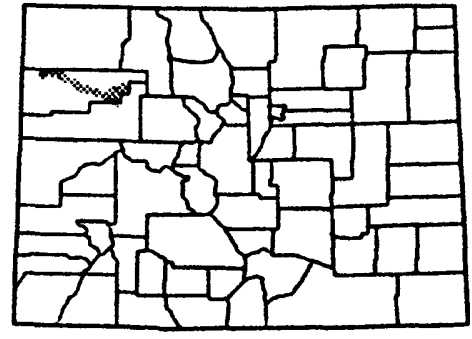

Colorado River Water Conservation District and Yellow Jacket Water Conservancy District

Robert L. Tobin, Field Office, Meeker

March 1984 to September 1989

PROBLEM: Sediments transported by rivers flowing into reservoirs are deposited throughout the length of the impoundment. Deposits may occur in the upper reaches of the reservoir that are controlled by hydraulics; as water depths increase and flow velocity decreases, bedload or coarser material is dropped first; subsequently, sand-sized material is deposited. Ultimately, finer silt and clay fractions in suspension are deposited, usually farther within the reservoir. To estimate total load and sedimentation rate, the following information is required: (1) Water discharge; (2) suspended-sediment concentration and size distribution; and (3) bedload-transport rate and size distribution.

OBJECTIVE: Measure the total inflow of suspended sediment and bedload into reservoirs or through reaches where reservoirs may be impounded. Estimate the effect of sediment deposition.

APPROACH: (1) Using standard techniques, collect suspended-sediment, bed material, and bedload data; (2) develop suspended-sediment, bedload, and total sediment-discharge relations, based on the collected data and on estimates from empirical techniques such as the Colby and modified Einstein equations; (3) compute annual sediment discharges at potential reservoir locations, using the sediment ratings and streamflow data; and (4) estimate trap efficiency of the reservoir, specific weight of the deposited sediment, and distribution of the sediment within the reservoir to assist in the design of reservoir structure and the operation of pilings.

PROGRESS: An interpretive report on the sediment characteristics of

Fortification Creek was completed and submitted for review. Two years of intensive data collections in the White River basin were completed in September 1988. Historical data on water quality and sediment for six sites on the White River were assembled from the Colorado data base, and formats for data presentations and analyses were initiated.

PLANS FOR FY 89: All data collected in 1988 will be reviewed and collated with the historical data base. An interpretive report will be written. The report will include data summaries, variations in data with changes in basin hydrology, and statistical presentations and analyses of data. 
PROJECT TITLE:

Wetland, Ground-Water, and SurfaceWater Relations in a Subalpine Valley in Grand County, Colorado

PROJECT NUMBER: $\quad$ CO-85-193

STUDY LOCATION: . North-central Colorado

COOPERATING AGENCY: City and County of Denver, Board

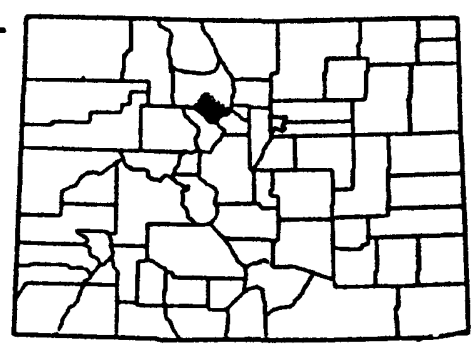
of Water Commissioners

PROJECT CHIEF AND

OFFICE:

Barbara C. Ruddy, Subdistrict Office, Denver

PROJECT DURATION: October 1984 to October 1989

PROBLEM: Surface water from the South Fork Williams Fork is being considered for diversion to another basin. Wetland areas along the banks of the South Fork receive water from precipitation and snowmelt, from valley side-slope flow, including overland and small-channel flow, from groundwater inflow, from riverbank overflow, or from a combination of these sources. If the wetlands are receiving substantial quantities of water from the river, then a decretion in river discharge may impact the wetland areas.

OBJECTIVES: Identify the hydrologic connection between the South Fork Williams Fork, the adjacent wetlands, and the wetland ground-water system. Evaluate the hydrologic effects of diverting water from the South Fork on adjacent wetlands.

APPROACH: Collect hydrologic data at four wetland sites and meteorological data at two stations. Design the we: i network at each site to define the geometry of the wetland water table; determine the direction of wetland ground-water flow from this information. Determine the water chemistry of the ground water and surface water and determine ground-water flow directions in the wetland. Determine if overbank flooding of the wetlands occurs. Combine the streamflow information with the wetland ground-water information to help delineate interaction between the river, the wetland ground water, and the wetlands.

PROGRESS: The hydrologic information that had been collected at all four wetland sites was insufficient to make conclusions at site 3 . Site 3 , particularly the east side of cross section $A$, was physiographically. different from the other wetlands. The wetland was located on a meander lobe confined on the east side by a steep, dry talus slope. A hydraulic potentiomanometer was used 4 times at site 3 to measure the difference in hydraulic head between the stream and ground water during different stream stages. The instantaneous hydraulic-head measurements were made across the meander lobe approximately parallel to the stream at eight locations in the wetland (at multiple depths, where possible). Water levels were measured at the two wells, and stream stage was measured at three or four locations. The data were used to construct potentiometric maps of the wetland for each of the four measurements. These maps were used to define generalized flow direction.

PLANS FOR FY 89: The project will be completed with an approved report. 
PROJECT TITLE:

Sediment-Transport Characteristics and their Effects on Aquatic Life in the Fountain Creek Basin above Widefield, Colorado

PROJECT NUMBER: $\quad$ CO-85-196

STUDY LOCATION: Colorado Springs and vicinity in

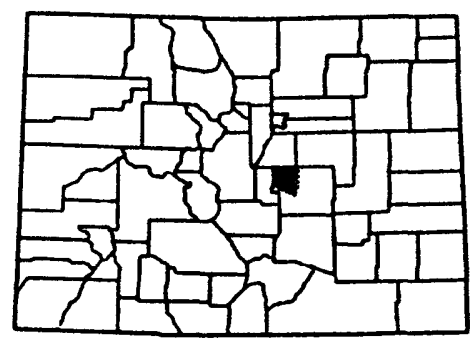
Arkansas River basin

COOPERATING AGENCY: City of Colorado Springs, Department of Utilities

PROJECT CHIEF AND

OFFICE:

Paul von Guerard, Subdistrict Office, Pueblo

PROJECT DURATION: January 1985 to September 1989

PROBLEM: Expanding urbanization in the Colorado Springs area is likely to increase stream-sediment loads during development. As development continues, the increase in impervious land areas may cause an increase in the magnitude and frequency of streamflow peaks. A resultant increase in bed scour and bank erosion will effect changes in channel morphology and may be detrimental to existing aquatic life. Increased channel erosion may affect riparian vegetation, stream-side recreation, diversion headgates, and other manmade structures.

OBJECTIVES: Define source areas of sediment and provide information on current sediment loads, on channel stability, and on changes observed during the study. Relate existing stream-sediment conditions to aquatic life in Fountain and Monument Creeks.

APPROACH: Incorporate systematic collection of sediment and biological data at a network of six sites and collect 50 sediment samples at each site. Collect three bedload samples per site and collect concurrently bottom material and suspended samples for full-size analysis. Establish channel cross sections at each site. Conduct biological sampling for benthic invertebrates at five sites. Delineate sediment-source areas by synoptic sampling at 20 sites.

PROGRESS: Collection of biological and sediment data continued and was completed at the end of the fiscal year. The report entitled "Suspended sediment and sediment source areas in the Fountain Creek drainage basin upstream from Widefield, Southeastern Colorado" was approved for publication.

PLANS FOR FY 89: Data collected during the study will be collated and analyzed. A report on sediment transport and its effects on aquatic life will be prepared, reviewed, revised, and submitted for approval and publication. 
PROJECT TITLE: $\quad$ Ground-Water-Quality Effects of Soil Application of Sewage Sludge on Farmland near Denver, Colorado

PROJECT NUMBER: $\quad$ CO-85-197

STUDY LOCATION: North-central Colorado

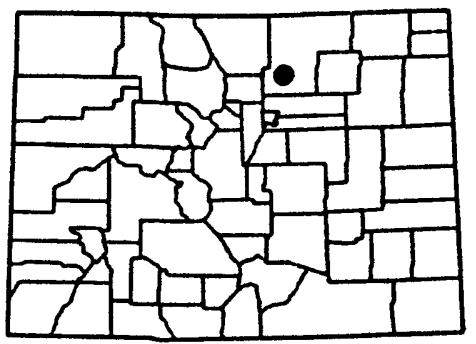

COOPERATING AGENCY: Metropolitan Denver Sewage Disposal District No. 1

PROJECT CHIEF AND

OFFICE:

Neville G. Gaggiani, Subdistrict Office, Denver

PROJECT DURATION: October 1984 to September 1989

PROBLEM: Metropolitan Denver Sewage Disposal District No. 1 is beginning a program of disposal of anaerobic, digested, activated sludge, by land application to farmland. The sludge will be injected about 6 to 10 inches into the soil, using a vehicle with a device that plows at the same time. Although the sludge will be applied at agronomic rates, the potential exists for leaching of organic and inorganic compounds into the ground water.

OBJECTIVE: Determine the effects of soil application of sewage on the groundwater quality. To accomplish this, determine the general flow rate, quantity, and quality of the water in the saturated and unsaturated zones.

APPROACH: After a suitable site has been selected, install piezometers, lysimeters, and a recording rain gage. Collect water samples from the saturated and unsaturated zone before sludge is applied, so that normal background conditions can be determined. After sludge is applied, sample the wells and lysimeters three times each growing season. Determine direction of flow from water levels in wells on and near the site. Use the Kendall rank correlation coefficient to test areal-concentrations variations.

PROGRESS: The observation wells were monitored for water levels and chemical quality during the growing season and in early spring. The water levels rose after the spring snowmelt and declined during the summer and fall. Nitrate concentrations increased with depth at three locations in the shallow aquifer.

PLANS FOR FY 89: The report will be completed. Ground-water levels will be measured monthly. The multi-level ground-water sampling devices and observation wells will be sampled for chemical analyses. Soil tubes will be measured with a neutron probe. 
PROJECT TITLE:

PROJECT NUMBER:

STUDY LOCATION:

Central Colorado

COOPERATING AGENCIES: Fountain Valley Authority; Pueblo Board of Water Works; Pueblo West Metropolitan District; St. Charles Mesa Water District; Southeastern Colorado Water Conservancy District; and U.S. Bureau of Reclamation

PROJECT CHIEF AND OFFICE:

PROJECT DURATION:
Comprehensive Water-Quality

Evaluation of Pueblo Reservoir, Including the Effects of

Potential Contamination

Co-85- 198

Central Colorado

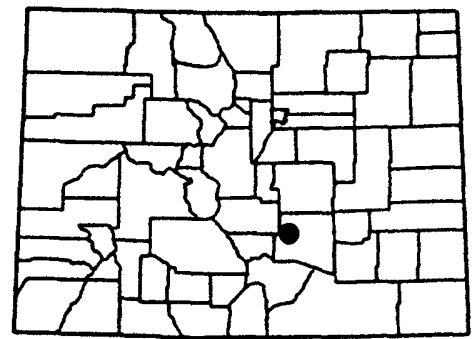

Patrick F. Edelmann, Subdistrict Office, Pueblo

March 1985 to September 1989

PROBLEM: Pueblo Reservoir is a multiple-use reservoir. Reservoir water is used for municipal, industrial, agricultural, and recreational purposes. Pueblo Reservoir receives storm runoff, salt loading from irrigationreturn flows, extensive recreational use, upstream mine drainage, and discharge from municipal and industrial wastewater. In addition, the quality of water in Pueblo Reservoir could be affected by upstream transportation spills. Concerns over potential water-quality problems that may affect Pueblo Reservoir's many uses have led to a comprehensive water-quality evaluation of Pueblo Reservoir.

OBJECTIVES: Determine areal, vertical, and seasonal variations of physical, chemical, and biological characteristics in Pueblo Reservoir. Develop methods to predict reservoir response to various contaminants. Evaluate management alternatives to maximize the reservoir's long-term suitability for various uses.

APPROACH: Collect and evaluate physical, chemical, and biological data on the reservoir inflow, the reservoir, and the reservoir outflow for 3 years. Compile and classify potential contaminants. Calibrate reservoir model to aid in understanding circulation patterns, residence-time, and stratification. Using information from the data-collection effort, the model, and the list of potential contaminants, predict reservoir response to various contaminants. Evaluate various management alternatives.

PROGRESS: Sediment-chemistry data were collected during October 1987 . All water-quality data were compiled, reviewed, and updated. The second of the three planned reports, that is, the "Compilation of water-quality data for Pueblo Reservoir and the Upper Arkansas River basin, Colorado, 1985-87" was completed. The report titled "Reconnaissance of water quality of Pueblo Reservoir, Colorado--May through December 1985" was approved for publication.

PLANS FOR FY 87: Analysis of physical, chemical, and biological data collected from Pueblo Reservoir during 1985-87 will be made. Residence and circulation patterns will be simulated using a computer model and mass loadings into and out of the reservoir will be calculated. Chemical sink and source terms for various chemical constituents will be determined. Mixing patterns, dilution curves, and potential reservoir response to contaminants will be determined. An interpretive report will be written. 
PROJECT TITLE: Federal Series Reports Preparation Center

PROJECT NUMBER: $\quad$ CO-85-199

STUDY LOCATION: Colorado District Office

COOPERATING AGENCY: None--U.S. Geological

Survey funds only

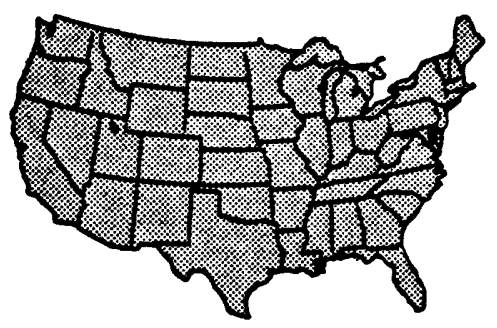

PROJECT CHIEF AND

OFFICE:

Edward J. Swibas, Colorado District Office, Denver

PROJECT DURATION: February 1985 to September 1989

PROBLEM: After submittal to the Geologic Division, the average time needed to prepare a formal series report for publication is about 18 months. Geologic Division's staff is not sufficient to prepare all illustrations for the large number of reports submitted within the time frame mandated by the Director.

OBJECTIVES: Provide support to the Branch of Scientific Publications at Headquarters (WRD) for the preparation of illustrations for Federal Series Reports. Reduce the backlog of approved Federal Series Reports not yet published. Provide WRD with a facility within the Division that provides quality preparation of illustrations, has working knowledge of the sciences, and a high level of expertise in visual communication. Employ the most efficient illustration-preparation techniques to decrease the time required to publish WRD Federal Series Reports.

APPROACH: Draft illustrations are sent to the Colorado Federal Series Reports Preparation Center to be prepared for printing. The Colorado Federal Series Reports Preparation Center designs and prepares final illustrations.

PROGRESS: Approximately 70 percent of all reports received since the beginning of the project has been completed.

PLANS FOR FY 89: Seven reports that were begun in 1987 will be completed. The number and type of newly assigned reports will be determined by the Chief Hydrologist for Scientific Publications and Data Management Staff in Reston, Virginia. 
PROJECT TITLE:

Trends in Water Quality of Monument and Fountain Creeks, EI Paso and Pueblo Counties, Colorado

PROJECT NUMBER: $\quad$ C0-85-200

StUdY LOCATION: El Paso and Pueblo Counties, Central Colorado

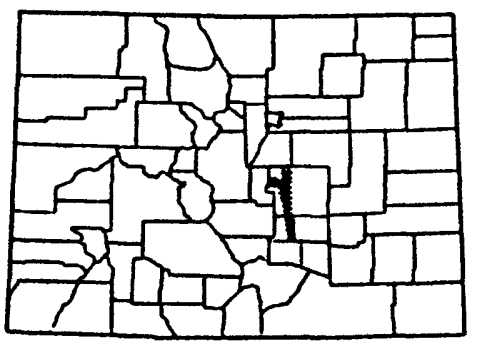

COOPERATING AGENCY: City of Colorado Springs, Department of Utilities

PROJECT CHIEF AND

OFFICE:

Barbara C. Ruddy, Subdistrict Office, Denver

PROJECT DURATION: January 1985 to September 1989

PROBLEM: Development of land and ground water in the Colorado Springs area is likely to cause changes in the water quality of Monument and Fountain creeks. These changes could cause water quality to become a limiting factor for some stream uses.

OBJECTIVES: Evaluate spatial changes in water quality of Monument and Fountain Creeks. Determine time trends for selected water-quality constituents, where data permit.

APPROACH: Continue water-quality-data collection on Monument and Fountain Creeks. Evaluate surface-water-quality data, using various statistical techniques to test for trends.

PROGRESS: Water-quality samples were collected monthly at four stations on Monument Creek and five stations on Fountain Creek. Samples were analyzed for nutrients, selected major constituents and trace constituents, 5-day biochemical oxygen demand, and bacteria. Water-quality data were reviewed, updated, and published in the colorado annual data report.

PLANS FOR FY 89: Spatial and temporal trends in water-quality constituents on Monument and Fountain Creeks will be determined. The report titled "Trends in water quality of Monument and Fountain Creeks, 1977-88" will be written. 
PROJECT TITLE: Mechanisms of Stream Recovery from Metal Contamination

PROJECT NUMBER: $\quad$ CO-86-217

STUDY LOCATION: Arkansas River near Leadville, Colorado

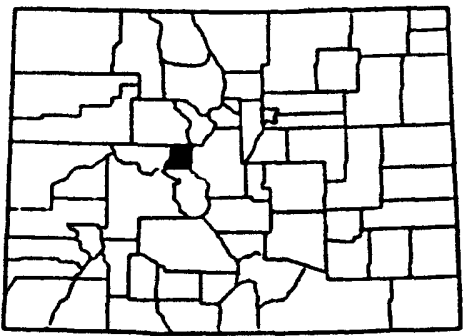

COOPERATING AGENCY: None--U.S. Geological Survey funds only

PROJECT CHIEF AND OFFICE:

Briant A. Kimbal1, District Office, Denver

PROJECT DURATION: February 1986 to September 1989

PROBLEM: Past mining of ore deposits in the Leadville, Colo., area has yielded economic quantities of gold, silver, copper, lead, zinc, iron, and bismuth. Water flowing through abandoned tailings and from adits in the Leadville area contributes large quantities of cadmium, copper, iron, lead, manganese, nickel, and zinc to the Arkansas River. Reactive solute-transport processes occurring within the channel are not well quantified. An interdisciplinary study of controls on trace-element concentrations in streams of the Leadville area will allow a better understanding of the transport and removal mechanisms controlling traceelement concentrations in streams in general.

OBJECTIVES: Characterize the within-stream chemical processes that control the transport and distribution of trace elements in streams of the Leadville area. Characterize the chemistry of sediment and sediment coatings that are active in controlling the dissolved concentrations of trace elements. Quantify the time and length scales for chemical and hydrologic processes that affect the metals and determine the extent to which chemical equilibrium has been attained. Characterize the effects of metals on biota in the acid streams.

APPROACH: Define the transition from natural conditions to areas affected by acid-mine drainage, using chemical mass balance to study reactions. Determine concentration, mineralogy, and particle-size distribution of suspended sediment, including colloids. Use in-stream transpōrt experiments to quantify time and length scales of chemical reactions.

PROGRESS: Work on photoreduction, sorption, and precipitation reactions that affect metal concentrations; studies of metal flux through the wetland in St. Kevin Gulch; mineralogy of precipitates in the acid drainage; metal concentrations in plants in St. Kevin Gulch; metal loadings into the Arkansas River from the major sources in the Leadville area; and solidphase chemistry from core samples taken from Pueblo Reservoir were summarized. This work is being done by Colorado District personnel with the collaboration of National Research Program (NRP) personnel, Geologic Division personnel, and Colorado School of Mines graduate students. An instream experiment was conducted in August 1988. Onsite chemical analyses indicated that metal concentrations were affected by the experimental increase of $\mathrm{pH}$ over an 8-hour period. Microbiological experiments were made that indicate very diverse communities in heavily affected and less affected areas in St. Kevin Gulch. 
PLANS FOR. FY 89: Work will begin on solute-transport modeling of 1986 data by Briant Kimball and Ken Bencala. This work is to prepare data for the journal paper on geochemical processes in St. Kevin Gulch. Preparation of the draft "planning" report will continue, summarizing the data collected by the Environmental Protection Agency (EPA) and other agencies. Chemical analysis of samples for the August 1988 experiment and the Pueblo Reservoir cores will continue. A data-base report will be prepared. Sampling will continue quarterly and weekly during the period of snowmelt runoff. Downstream sampling of the Arkansas River from Leadville to Pueblo Reservoir will be conducted to trace the chemistry of colloids. 
PROJECT TITLE:

PROJECT NUMBER:

STUDY LOCATION:
Effects of Current and Projected Wastewater Effluents on Fountain and Monument Creeks, Colorado

C0-86-218

Fountain and Monument Creeks, Central Colorado

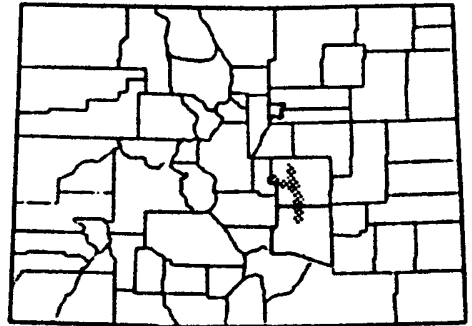

COOPERATING AGENCY: Pikes Peak Area Council of Governments

PROJECT CHIEF AND

OFFICE:

Gerhard Kuhn, Subdistrict Office, Pueblo

PROJECT DURATION: April 1986 to September 1989

PROBLEM: Fountain and Monument Creeks receive wastewater effluent from numerous communities and developments. Because of future population growth in the area, wastewater discharges to the creeks are expected to increase, possibly causing violations of State stream water-quality standards and degrading stream classifications. No means currently are available to assess the impact of current and projected wastewater effluents on Fountain and Monument Creeks.

OBJECTIVES: Calibrate and verify a one-dimensional surface-water-quality model for Fountain and Monument Creeks for constituents commonly associated with wastewater effluents. Use the calibrated and verified model to simulate projected wastewater-management plans. Estimate concentrations of nonionized ammonia in the creeks.

APPROACH: Collect and evaluate water-quality data for 24-hour periods as near the 7-day, 10-year low flow as possible for seasons of critical waterquality conditions. Conduct traveltime and reaeration studies at two-flow regimes. Use existing methods to estimate concentrations of nonionized ammonia in the streams. Adopt a one-dimensional surface-water-quality model to the stream.

PROGRESS: All data have been compiled and analyzed. A data report has been prepared and submitted for approval. The U.S. Environmental Protection Agency's QUAL2E model was selected as the most appropriate model to complete the modeling aspects of the study. The program code was obtained in late July 1988; numerous changes to the code were made to provide more flexibility in application of the model to Fountain and Monument Creeks. Preliminary model runs were completed.

PLANS FOR FY 89: Calibration and verification of the QUAL2E model will be completed. The final report will be written, colleague reviews will be responded to, and the report will be submitted for approval and publication. The data report will be published. 
PROJECT TITLE:

Hydrology and Geochemistry of Reclaimed Coal Spoils in Northwestern Colorado

PROJECT NUMBER:

C0-86-222

STUDY LOCATION:

Northwestern Colorado

COOPERATING AGENCIES: Colorado Department of Natural Resources,

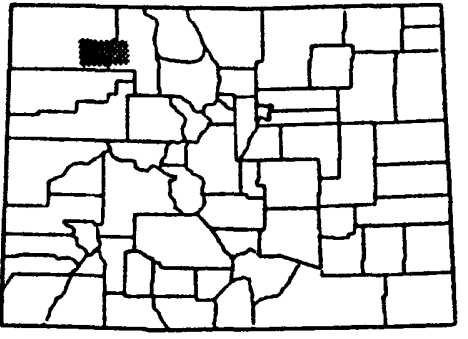

Division of Mined Land Reclamation; U.S. Bureau of Land Management, and U.S. Office of Surface Mining Reclamation and Enforcement

PROJECT CHIEF AND OFFICE:

Robert S. Williams, Jr., District Office, Denver

PROJECT DURATION: January 1987 to September 1990

PROBLEM: Regulatory and management agencies determine site suitability for surface coal mining. The agencies need to be able to determine the quantity and quality of water that could flow through and discharge from a reclaimed coal spoil. The agencies also need to know the duration of any impacts. Quantity, quality, and duration information can assist agencies in regulatory and management decisions.

OBJECTIVES: Describe the processes controlling the hydrology of reclaimed coal spoils. Determine the sources of recharge to and discharge from reclaimed coal spoils. Determine the rate of water movement through reclaimed coal spoils. Determine the geochemistry of a reclaimed coal spoil and the magnitude of change in concentrations of dissolved constituents in reclaimed coal-spoil discharge.

APPROACH: Hydrologic monitoring equipment is installed at selected sites to monitor water flows into, through, and from reclaimed coal-mined land. Instrumentation includes weather monitoring equipment, soil-water access tubes, lysimeters, ground-water wells, and streamflow gages. Reclaimed coal-mined land sources of recharge and points of discharge will be determined by using the instrumentation information, flow models, and geochemical models.

PROGRESS: All instrumentation was monitored on schedule during the year. Aquifer tests were run, core laboratory work was completed. Initial work on the hydraulic model was begun. Aquifers in the area have distinct water types and dissolved-solids concentrations.

PLANS FOR FY 89: Data collection will continue as scheduled. Personnel will proceed with interpretation and analysis of data. 
PROJECT TITLE: Acidification of Lakes along the Colorado Front Range

PROJECT NUMBER: $\quad$ CO-87-223

STUDY LOCATION: Colorado Front Range

COOPERATING AGENCIES: Colorado Department of Health, U.S. Environmental Protection

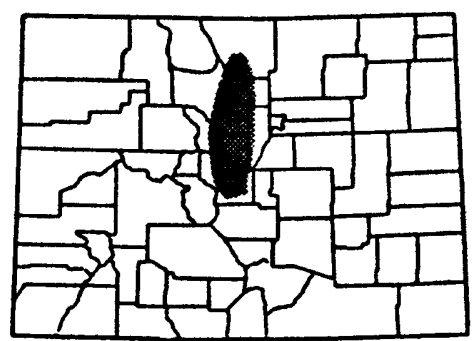
Agency, and U.S. Geological Survey

PROJECT CHIEF AND

OFFICE:

John T. Turk, District Office, Denver

PROJECT DURATION: January 1987 to September 1989

PROBLEM: Estimates of acidification quantities for lakes along the Colorado Front Range are based on unreliable historical data, because of uncertainty in the effect of differences in precipitation, sampling, and analytical procedures during periods of data collection.

OBJECTIVES: Determine acidification quantities for lakes along the Colorado Front Range; validate a model that estimates lake chemistry from watershed characteristics. Test a new model that determines whether a lake watershed is conservative with respect to sulfate to determine whether the model is transferable to other areas.

APPROACH: Determine acidification quantities by using a model based on regional lake-sulfate concentrations. Resample most, or all, of the lakes used in the original comparison; determine all major ions; select a subset of lakes to determine the variance to pH and alkalinity diurnally and seasonally to ensure reliability of the statistical significance of the results.

PROGRESS: Daily samples were collected at Brainard Lake to determine the effect of snowmeit. Biweekly samples were collected at five other sites.

PLANS FOR FY 89: Sulfur-isotope data will be used to distinguish between atmospheric and watershed sources of sulfate. 
PROJECT TITLE: $\quad$ Application of a Geographic Information System to Determine the Vulnerability of Ground-Water Resources in the Greater Denver Area

PROJECT NUMBER: $\quad$ CO-87-224

STUDY LOCATION: Central Colorado

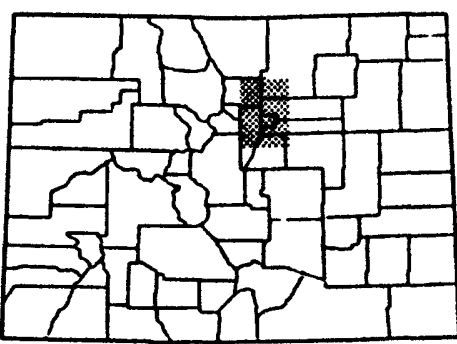

COOPERATING AGENCY: Colorado Department of Health

PROJECT CHIEF AND OFFICE:

Glenn A. Hearne, District Office, Denver

PROJECT DURATION: June 1986 to September 1989

PROBLEM: Programs for planning, regulating, and monitoring ground-water resources are hampered by the lack of data that are readily accessible in a usable format. Although individual programs have compiled data compatible with specific objectives, these programs do not provide products useful for regional planning.

The National Water Well Association (NWWA) has developed a technique for comparing the relative vulnerability of ground water to contamination (Alier and others, 1985). Preparation of maps showing relative vulnerability generally entail tedious and costly manual procedures. To map relative vulunerability for regional areas, methods are needed to access the available data and to process data using computerized techniques.

Regional planning requires information about the spatial relations between relative vulnerability of ground water and several other mappable characteristics such as land use, potential sources of contamination, demographics, and water use. By using paper maps, this task would entail the production of multiple maps or a complex group of registered overlays. And for some of the characteristics shown, the data in the data base are changing rapidly enough that the data may be outdated shortly after the map has been published.

OBJECTIVE: Develop a map (or maps) of the study area showing the relative vulnerability of ground water in the uppermost aquifer to contamination from sources on the land surface. Methods used will be documented to aid in transferring techniques to priority areas in Colorado and other States. 
APPROACH: The project will be a team effort involving the Colorado Department of Health (CDH), the U.S. Environmental Protection Agency Region VIII Water Management Division (EPA-WMD) and Environmental Studies Division (EPA-ESD), the U.S. Geological Survey Water Resources Division (USGS-WRD) and National Mapping Division (USGS-NMD), and the U.S. Soil Conservation Service (SCS).

For the study area, identify data sources for the characteristics needed to compare relative ground-water vulnerability in the uppermost aquifer. The characteristics considered will include at least the following:

Depth to ground water, recharge rate, aquifer media type, soil type, topography, impact of the vadose zone, hydraulic conductivity, hydrogeologic setting, secondary permeability, and hydraulic connection with deeper aquifers.

Develop selected environmental coverages (that is, RCRA, CERCLA, UST, and landfills) to maximize utility of the relative ground-water vulnerability map in regional planning. It is anticipated that these covers will be developed by $\mathrm{CDH}$ and EPA. Use the ARC/INFO GIS to calculate and map the relative vulnerability of ground water by using selected attribute data that have been integrated into ARC/INFO. Describe the format, access, and quality of data sources used for this study. Compare the mapped relative vulnerability with observed conditions. This comparison may include sensitivity tests, colleague reviews, and field tests. Prepare a report presenting the results of the project.

PROGRESS: Secondary hydrogeologic settings have been identified in the pilot area using the digitized geologic map. The depth-to-water and geologic maps $(1: 100,000)$ have been drafted in-house and scanned under contract. The soil associations mapped at 1:250,000 have been identified and tabulated by SCS. A technique for generalizing from soil textures to soil horizons to soil series to soil associations has been agreed upon by the agency representatives and applied to all soil series included in soil associations in the study area. DEM's have been acquired in scale $1: 24,000$, where available, and in scale 1:250,000 for other areas. A program has been developed to convert PLS locations to latitude/longitude and map. This program will be useful for the State Engineer's well data base and other environmental covers of interest to $\mathrm{CDH}$ and EPA.

PLANS FOR FY 89: A technique for decreasing the number of small polygons of map units developed from the geologic map and a technique for limiting the number of small polygons generated by intersecting separate covers will be developed and applied. DEM data to accommodate data-generation methods and produce a cover of percent slope for the pilot study area will be processed. Work with $\mathrm{CDH}$ and EPA in their efforts to develop "environmental" covers will be continued. EPA personnel may be available to digitize (under the direction of U.S. Geological Survey personnel) environmental covers. A 1:100,000 base map will be developed. A relative vulnerability map for the pilot area will be revised, and similar methods will be applied to the map of the study area. 
PROJECT TITLE:

PROJECT NUMBER:

STUDY LOCATION:

COOPERATING AGENCIES:
Hydraulic Characteristics of Confined Clastic Aquifers at Castle Pines, Colorado

CO-88-225

6 miles northwest of Castle Rock, Colorado

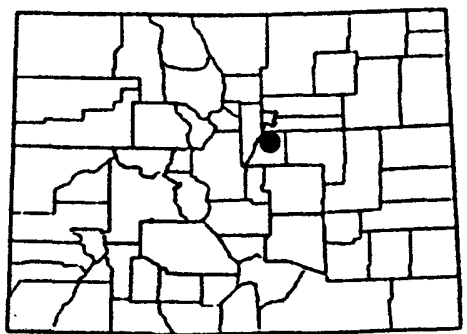

Castle Pines Metropolitan District;

Castle Pines North Metropolitan District; and

Colorado Department of Natural Resources, Division of Water Resources, Office of the State Engineer

PROJECT CHIEF AND OFFICE:

Stanley G. Robson, District Office, Denver

PROJECT DURATION:

October 1987 to September 1989

PROBLEM: Accurate determination of aquifer characteristics in deep bedrock aquifers is of increasing concern because of growing demands for freshwater produced from such aquifers. Present techniques for estimating aquifer characteristics, such as specific yield, hydraulic conductivity, porosity, and specific storage, involve core drilling and laboratory analyses, which are time-consuming and costly. Recent technological advances in geophysical logging indicate the potential for rapid and accurate determination of aquifer characteristics from interpretation of new geophysical logs.

OBJECTIVES: (1) To refine existing log-interpretation techniques, or develop new techniques, for use with new geophysical logs; (2) to compare coreanalysis results, geophysical $\log$ response, and aquifer-test results to assess accuracy and applicability of these techniques; and (3) to evaluate well-bore temperature, formation compression, and pressure response data as possible indicators of aquifer characteristics.

APPROACH: A new well will be drilled adjacent to an existing core hole to allow additional geophysical logging and construction of a cased observation well. Aquifer tests will be run using a nearby pumping well and packer-isolated transducers in the observation well. Core-sample analyses, geophysical log response, and aquifer-test results will be correlated to evaluate feasibility of various techniques for determining aquifer characteristics.

PROGRESS: A 2,400-foot-deep observation well was constructed near an irrigation well and a core hole of similar depth at the study site in Castle Pines, Colorado. About 350 laboratory determinations of core porosity and specific yield have been made on samples from the core hole. Correlation of core data with geophysical logs has begun in an effort to evaluate the potential for determining aquifer specific yield from geophysical logs. Results of aquifer-strain measurements made during an aquifer test support a new technique for determining confined storage coefficient. Results of the technique have been corroborated by barometric-efficiency data.

PLANS FOR FY 89: Work will continue on correlation of core data with geophysical log data. A basic-data report will be assembled when final laboratory data are available. An interpretive report will be prepared to document findings of the study. 
PROJECT TITLE:

Statistical Analys is of WaterQuality Data from Selected Sites in the South Platte River Basin and the Colorado River Basin in Colorado

PROJECT NUMBER: $\quad$ C0-88-227

STUDY LOCATION: North-central Colorado

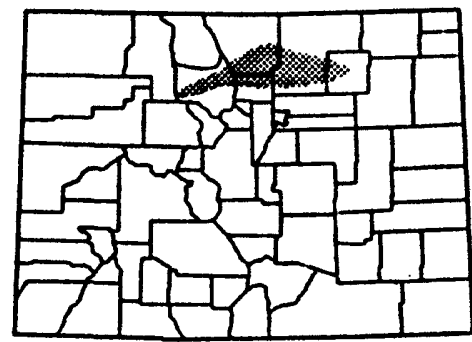

COOPERATING AGENCY: Northern Colorado Water Conservancy District

PROJECT CHIEF AND

OFFICE:

David K. Mueller, Subdistrict Office, Denver

PROJECT DURATION: October 1987 to September 1989

PROBLEM: Recent and potential changes in water-quality regulations and regulatory authority have raised questions about the existing waterquality network for the Colorado-Big Thompson project. Before changes are made to the frequency, constituents, or number of sites sampled in the 10-station network, a statistical analysis of existing data is needed to provide information for management decisions.

OBJECTIVES: (1) Determine whether the frequency of sampling for individual water-quality parameters at the selected sites could be decreased without substantial loss of information. (2) Determine whether any significant correlations exist between stations or between parameters at individual stations.

APPROACH: Statistical techniques will be used to estimate records from a partial data set for each station. These estimates will be compared to the unused data to determine the error caused by decreasing the sampling frequency. Correlations between parameters and between sites will be computed to identify relations that may be used to extend the existing records.

PROGRESS: All analyses were completed. A draft report was written and submitted for review. Results were presented to the cooperators and were used to modify the sampling and analysis programs in the study area.

PLANS FOR FY 89: The review and approval process for the final report will be completed. A presentation of the methods used in the study will be made at a symposium on the design of water-quality networks. 
PROJECT TITLE: National Ground-Water Atlas

PROJECT NUMBER: $\quad$ CO-88-229

STUDY LOCATION: $\quad$ Nationwide

COOPERATING AGENCY: None--U.S. Geological Survey

funds only

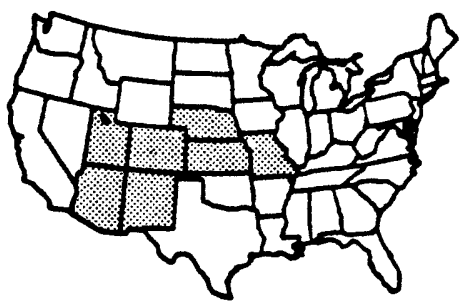

PROJECT CHIEF AND

OFFICE:

Stanley G. Robson, District Office, Denver

PROJECT DURATION: October 1987 to October 1990

PROBLEM: A unified summary of ground-water conditions in the Nation is needed. The Regional Aquifer System Analysis (RASA) program provides regional summaries of ground-water information, but the results of this program have not been compiled to produce a national picture. A National Ground-Water Atlas will summarize in one publication the most important ground-water information the U.S. Geological Survey has collected and published over many years. It also will serve as a ready source to answer ground-water inquiries from consultants, other Federal agencies, and the congressional staffs.

OBJECTIVE: (1) To provide a summary of the Nation's ground-water resources for readers that include the lay public, consultants, planners, colleges and universities, congressional staffs, and other governmental agencies. (2) To synthesize ground-water information that now exists at many scales into a single document that can be used to respond to requests for information from the above groups and others.

APPROACH: (1) Synthesis and merging of existing interpretations, starting with those of the RASA program; (2) separation of the Country into 13 multi-State segments and assignment of each segment to an experienced hydrologist charged with assembling all materials necessary to present hydrologic conditions for all important aquifers in that segment; and (3) obtaining limited new maps and other products from districts as needed. Segments 2 and 3 will be completed by this project. Segment 2 includes Kansas, Missouri, and Nebraska. Segment 3 includes Colorado, Arizona, New Mexico, and Utah.

PROGRESS: All source material for segment 3 has been read and most material. has been summarized. The appraisal of the High Plains aquifer is nearly complete. Several illustrations have been prepared, and some text has been written for the stream-valley aquifers, the Western Interior Plains aquifer system, the Great Plains aquifer system, and the Ozark Plateaus aquifer system.

PLANS FOR FY 89: Segment 3 describing the aquifers and ground-water conditions within the area will be completed. Planned work on segment 2 will be started and completed. 
PROJECT TITLE: Irrigation-Drainage Field-Screening Study of the Middle Arkansas River, Colorado and Kansas

PROJECT NUMBER:

C0-88-230

STUDY LOCATION: SOutheastern Colorado

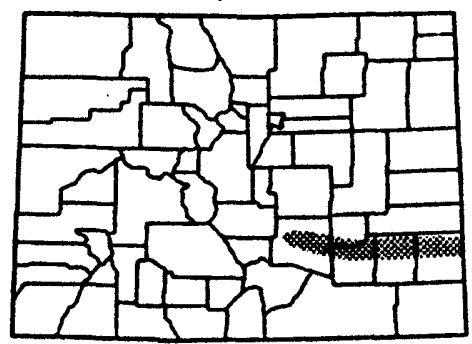

COOPERATING AGENCY: None--U.S. Geological Survey funds only

PROJECT CHIEF AND OFFICE:

David K. Mueller, Subdistrict Office, Denver

PROJECT DURATION: November 1987 to September 1989

PROBLEM: Contamination from agricultural drainage has had adverse effects on fish and wildlife in some locations of the Western United States. Concentrations of trace elements found in drainage water at some sites also are large enough to cause concerns for human health. Screening studies are needed to determine where drainage from large irrigated areas may be contaminating wildlife areas or water supplies.

OBJECTIVE: Determine whether drainage from irrigated land along the Arkansas River between Pueblo, Colo., and Garden City, Kans., has caused or has the potential to cause harmful effects on human health, fish, or wildlife, or might reduce the suitability of water for beneficial uses.

APPROACH: Water-quality samples will be collected at seven locations along the Arkansas River and from two tributaries. Samples also will be collected from four reservoirs that receive irrigation drainage water and from four municipal well fields located in the alluvial aquifer along the Arkansas River. The U.S. Fish and Wildlife Service (USFWS) will collect concurrent biota samples at all surface-water sites. The data will be summarized in a water-resources investigations report.

PROGRESS: Selenium concentrations were smaller than 10 micrograms per liter in all reservoirs. Specific conductance as large as 2,940 microsiemens per centimeter was measured in the Arkansas River and 4,410 microsiemens per centimeter in alluvial ground water.

PLANS FOR FY 89: When laboratory results are available, data will be tabulated along with any previous data. A presentation will be made at a national program review meeting in February, and the report will be written during March 1989. 
PROJECT TITLE:

Irrigation-Drainage Reconnaissance of the Gunnison River and Sweitzer Lake, west-central Colorado

PROJECT NUMBER: $\quad$ CO-88-231

STUDY LOCATION: West-central Colorado

COOPERATING AGENCY: None--U.S. Geological Survey funds only

PROJECT CHIEF AND

OFFICE:

David L. Butler, Subdistrict Office, Grand Junction

PROJECT DURATION: November 1987 to September 1989

PROBLEM: Substantial concentrations of selenium have been reported by the Colorado Division of Wildlife in fish, water, and bottom material from Sweitzer Lake near Delta. Moderately large concentrations of selenium occasionally are reported for the National Stream Quality Accounting Network (NASQAN) station Gunnison River near Grand Junction. The source of the selenium may be irrigation drainage entering the lake and the lower Uncompahgre River from the Uncompahgre Project administrated by the U.S. Bureau of Reclamation (USBOR). The Sweitzer Lake area was among several sites selected for a field-screening study by the Department of the Interior's (DOI) policy team for irrigation drainage.

OBJECTIVE: To determine if the Uncompahgre Project Area is contributing selenium, other trace elements, and pesticides to water, bottom material, birds, fish, and aquatic plants and animals in the lower Uncompahgre River basin, the Gunnison River, and Sweitzer Lake. This is a reconnaissance study to determine if there are water-quality problems associated with irrigation drainage from projects administered by the Department of the Interior.

APPROACH: The U.S. Geological Survey (USGS) is responsible for the waterquality sampling for the study. Four sampling surveys will be conducted. Water samples for inorganic analyses of major constituents and trace elements will be collected from the Gunnison and Uncompahgre Rivers upstream and downstream from the irrigation-drainage area. Water samples for the same analyses will be collected from Sweitzer Lake, Garnet Canal diversion, and the Sweitzer Lake outflow. Bottom-material samples from Sweitzer Lake and the Gunnison and Uncompahgre Rivers will be analyzed for trace elements. In addition, samples for pesticide analyses of bottom material will be collected from Sweitzer Lake and the Gunnison River downstream from Delta. Biological sample collection and analysis will be done by the U.S. Fish and Wildlife Service (USFWS). 
PROGRESS: Water-quality surveys were done in November, January, March, and July at sites on the Gunnison and Uncompahgre Rivers and at Sweitzer Lake. Small increases of selenium were noted in the Gunnison River from the background site at the Gunnison Tunnel to the site at Delta. Substantial increases in selenium concentrations were noted in the November and January surveys for the Uncompahgre River from Colona to Delta. Concentrations at Delta were 33 and 34 micrograms per liter. Selenium concentrations increased in Sweitzer Lake from 10 micrograms per liter in November to from 23 to 25 micrograms per liter in March. Water near the bottom of the lake had zero dissolved oxygen and selenium concentration of 170 micrograms per liter in March. There were large selenium concentrations in the Garnet Canal turnout at Sweitzer Lake; the largest selenium concentration was 320 micrograms per liter in March. Selenium concentrations in the lake and canal were considerably fewer in July than in March.

PLANS FOR FY 89: Analytical results will be reviewed as they become available, and data analysis will be completed. The final report will be written. Report sections on biota will be written by the study team member from the U.S. Fish and Wildlife Service. 
PROJECT TITLE:

PROJECT NUMBER:

STUDY LOCATION:

COOPERATING AGENCIES:
Water-Quality Evaluation of the Arkansas River Basin

$\mathrm{CO}-88-232$

Arkansas River basin, southeastern Colorado

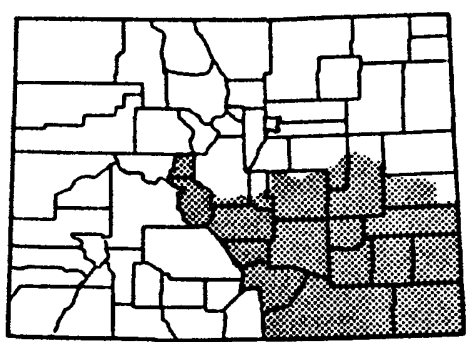

City of Colorado Springs, Department of Utilities;

Pueblo Board of Water Works; Pueblo County;

Pueblo West Metropolitan District;

St. Charles Mesa Water District;

Southeastern Colorado Water Conservancy District;

Upper Arkansas Council of Governments;

Upper Arkansas River Water Conservancy District

PROJECT CHIEF AND OFFICE:

Doug Cain, Subdistrict Office, Pueblo

PROJECT DURATION: January 1988 to September 1989

PROBLEM: The sensitivity of important water uses to small changes in water quality, coupled with numerous actual or proposed changes in water use or administration during recent years, have focused increased attention on the need to protect water quality. Available water-quality data have not been evaluated for their adequacy in addressing many of the water-quality concerns that currently exist, nor have these data been applied in conjunction with appropriate techniques of hydrologic analysis to predict the effects of man-induced changes in the basin.

OBJECTIVE: (1) To identify water-quality concerns in the basin that are amenable to evaluation through hydrologic data collection and analysis, (2) to compile available data and evaluate their adequacy to address those concerns, and (3) to develop a detailed plan to evaluate the waterquality concerns identified. The evaluation will be Phase 2 of the investigation.

APPROACH: Identify water-quality concerns through extensive consultation with local agencies. Restate the identified concerns in terms of the waterquality constituents of interest, the relevant water-quality processes, and the affected stream reach. Select appropriate techniques of hydrologic analysis and determine data needs. Compile and evaluate available data and design a plan for additional data collection. Prepare a detailed plan for the second phase of study.

PROGRESS: Contacts have been made with approximately 40 different agencies to obtain input on water-quality concerns, and meetings have been held with all cooperating agencies. Compilation of available water-quality information has begun. Preliminary evaluation of available tools for hydrologic analysis has begun.

PLANS FOR FY 89: Evaluation of available data and tools of hydrologic analysis will be completed. A detailed study plan for Phase 2 of the project will be prepared. 
PROJECT TITLE: High Plains Water-Level Network

PROJECT NUMBER: $\quad$ C0-88-233

STUDY LOCATION: High Plains of eastern Colorado

COOPERATING AGENCY: Colorado Department of Natural

Resources, Division of Water

Resources, Office of the

State Engineer

PROJECT CHIEF AND

OFFICE:

William P. Van Liew, District Office, Denver

PROJECT DURATION: $\quad$ August 1988 to September 1992

PROBLEM: The High Plains aquifer is the principal source of water for much of eastern Colorado. Historical pumpage has caused substantial water-level declines in some areas. Since the end of Phase I of the High Plains Regional Aquifer System Analysis (RASA) study in 1983, the number of water-level measurements has declined considerably, no interpretation of the data has been made, and no information about the seasonal variation has been collected.

OBJECTIVE: To enhance the water-level network of the High Plains, to identify the seasonal variation of water levels, and to determine areas of waterlevel change.

APPROACH: Personnel of the Office of the State Engineer will measure approximately 700 wells in the High Plains annually. The data will be entered into the Ground-Water Site Inventory (GWSI) system and screened for consistency and possible errors. Some wells will be remeasured and additional wells measured by the U.S. Geological Survey (USGS). Continuous recorders will be operated to monitor the seasonal variation. Trends in water levels will be evaluated, and areas of substantial water-level change will be mapped.

PROGRESS: Five wells were equipped with continuous recorders after a reconnaissance trip during which nearly 20 wells were checked and measured. About 550 water-leve 1 measurements made during the 1987-88 winter by Office of the State Engineer personnel were entered into Ground-Water Site Inventory. Two sources of historic long-term records were located, and data have been added to Ground-Water Site Inventory. Analysis of water-level changes was provided for the regional report.

PLANS FOR FY 89: Another mass measurement of approximately 600 wells will be made, and the 5 recording wells will be continued. A single-sheet report will be produced to display water-level changes and hydrographs. 
PROJECT TITLE:

PROJECT NUMBER:

STUDY LOCATION:
Probability analysis of daily floodflows into Pueblo Reservoir during April and May

C0-89-234

Arkansas River basin upstream from Pueblo Reservoir

COOPERATING AGENCY: Southeastern Colorado Water Conservancy District PROJECT CHIEF AND OFFICE:

Gerhard Kuhn, Subdistrict Office, Pueblo

PROJECT DURATION: October 1988 to June 1992

PROBLEM: Pueblo Reservoir, located 10 miles west of Pueblo, Colo., is one of the principal features of the Fryingpan-Arkansas Project, a waterdevelopment project of the U.S. Bureau of Reclamation. Part of the storage space in Pueblo Reservoir consists of a 66,000 acre-foot jointuse pool that can be used to regulate imported and native waters for municipal, industrial, and irrigation uses during the period November 15 through April 14. During the original design of Pueblo Dam, the U.S. Army Corps of Engineers designated April 15 as the date each year by when the joint-use pool must be vacated for additional flood-control storage. The possibility of using water stored in the joint-use pool even a brief time beyond April 15, typically the beginning of the growing season, is very important to the economic interests: of water users and to the wise management of water resources. In addition, the long-term yield of the joint-use pool would be increased if the April 15 date were extended during some years when hydrologic and climatic conditions were favorable.

OBJECTIVES: The objectives of the study are to (1) Assess the daily probability of floodflows into Pueblo Reservoir during April and May on the basis of historic streamflow data, and (2) develop a method for evaluation of the risks of allowing extended storage in the joint-use pool in Pueblo Reservoir based on real-time data during April and May of each year.

APPROACH: The approach will consist of several steps: (1) Evaluate the Precipitation-Runoff Modeling System, the National Weather Service River Forecast System model, or other appropriate models for applicability to the study and select the most appropriate model; (2) develop basin characteristics needed to operate the hydrologic model by using a GeographicInformation System; (3) develop a data base of historic streamflow and climatologic data; (4) calibrate and verify the hydrologic model with independent data sets; (5) couple the calibrated model with Extended Streamflow Prediction procedure to provide probabilistic estimates of future daily flood volumes and peak discharges on the Arkansas River at Pueblo Reservoir.

PLANS FOR FY 89: A detailed work plan for the study will be prepared. Types and availability of hydrologic models suitable to the study will be investigated, and the most appropriate model will be selected. A geographic information system will be acquired, and basin parameters used in model input will be developed. The compilation of climatic and streamflow data to be used to calibrate and verify the hydrologic model will be initiated. 
PROJECT TITLE: National Water Summary Report Preparation Center

PROJECT NUMBER: $\quad$ CO-89-235

STUDY LOCATION: Nationwide

COOPERATING AGENCY: None--U.S. Geological Survey funds only

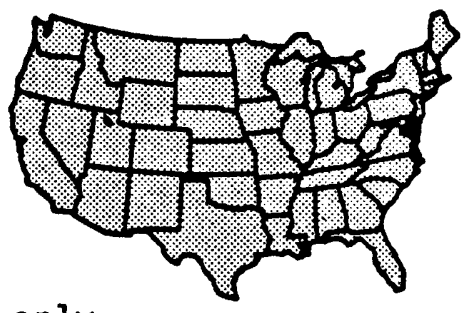

PROJECT CHIEF AND OFFICE:

Linda J. Britton, District Office, Denver

PROJECT DURATION: October 1988 to September 1990

PROBLEM: Delays in planned publication dates for National Water Summary reports have created the need to obtain additional personnel and technical-resource support in order to produce quality reports in a timely manner.

OBJECTIVES: Create a National Water Summary Report Preparation Center in the Colorado District to assist in editorial, manuscript preparation, and graphics support for biennial production of the National Water Summary report. This Center would ease demand on the scientific illustrators with the Office of Scientific Information Management (SIM) at Headquarters, drastically decrease the cost of detailing WRD editors and typists to Headquarters, provide more efficient processing and timeliness to the publication of the report, and improve the image of the U.S. Geological Survey.

APPROACH: Manuscripts will be sent to the National Water Summary Report Preparation Center in Colorado for editing, retyping, and proofreading. The project chief and illustrator initially would be involved with the design and planning of the biennial report. Graphics support would include design and scribing of maps for layout of report front-part boards in Reston.

PROGRESS: All the proposed staffing positions required for assisting in the production of National Water Summary reports have been filled. Present staff members have been involved in three progress meetings with other Preparation Center personnel and in an initial design meeting for the 1990-91 report. Approximately 100 optional illustrations and 52 waterbudget diagrams were prepared for State summaries for the 1987 National Water Summary report. Two illustrations for the front part of the 1987 National Water Summary report have been prepared.

PLANS FOR FY 89: Equipment needed for assisting in the preparation of the 1987, 1988-89, and 1990-91 reports will be purchased. Final corrections to the optional illustrations for the State summaries and final corrections to the water-budget diagrams will be completed. Specifications for the remainder of front-part illustrations will be received, approximately 10 illustrations will be prepared, and final corrections will be made. 
PROJECT TITLE:
Irrigation-Drainage

Reconnaissance of the

Pine River Area, Southern

Ute Reservation,

Southwestern Colorado

PROJECT NUMBER: $\quad$ C0-89-236

STUDY LOCATION: Ignacio, Colorado

COOPERATING AGENCY: None--U.S. Geological Survey funds only

PROJECT CHIEF AND

OFFICE:

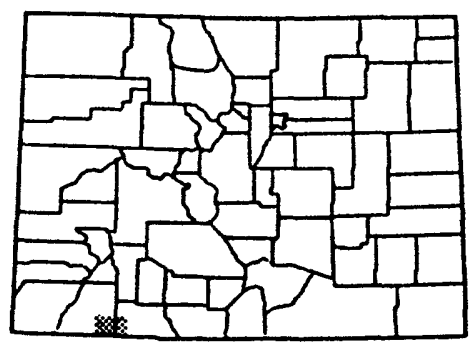

David L. Butler, Subdistrict

Office, Grand Junction

PROJECT DURATION: October 1988 to September 1990

PROBLEM: Large concentrations of selenium have been reported in the ground water on parts of the Southern Ute Reservation in southwestern Colorado. These areas also receive irrigation water from the U.S. Bureau of Reclamation's Pine River project. A documented case of human selenium poisoning caused by drinking well water occurred in 1962 . Reports of occasional poisoning of horses and livestock are reported on the Reservation. Application of irrigation water to land containing large quantities of selenium could transport selenium into the ground-water system and to streams receiving drainage water. The Pine River area was selected for a reconnaissance-level investigation by an interbureau task group from the Department of the Interior (DOI) to identify water-quality problems that may be caused by irrigation drainage from projects constructed or managed by the Department of the Interior.

OBJECTIVE: The objective is to determine if water from the Pine River project is contributing selenium, other trace elements, and pesticides to water, bottom sediment, and biota in watersheds draining the project area on the Southern Ute Indian Reservation.

APPROACH: Collect water-quality samples for major ion and selected traceelement analysis of 17 stream sites and 5 wells. Streams will be sampled after the irrigation season, prior to the irrigation season, and during the irrigation season. Wells will be sampled during winter and summer. Outflow sites will be sampled during summer for herbicides. Selected outflow sites and Navajo Reservoir will be sampled for bottom sediments for trace elements and pesticides. Biota sampling for birds, fish, invertebrates, and aquatic plants will be done during three surveys. Biota sampling and analysis will be done by the U.S. Fish and Wildlife Service.

PLANS FOR FY 89: Samples will be collected from stream, wells, and biota for inorganic and herbicide analyses. Bottom-material samples will be collected at selected sites for inorganic and organochloride-insecticide analysis. 
PROJECT TITLE:

PROJECT NUMBER:

STUDY LOCATION:

COOPERATING AGENCY:
Pueblo Depot Activity Ground-Water Monitoring

C0-89-237

Pueblo Depot Activity, Colorado

U.S. Department of the Army, Pueblo Depot Activity, Pueblo

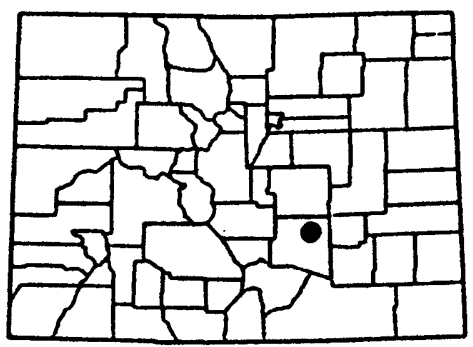

PROJECT CHIEF AND OFFICE:

Kenneth R. Watts, Subdistrict Office, Pueblo

PROJECT DURATION: October 1988 to September 1989

PROBLEM: The Pueblo Depot Activity is one of the sites selected by the U.S. Army for destruction of the Pershing rocket motors under International Treaty. An assessment of environmental quality, including the chemical quality of ground water is required prior to destruction and disposal of the rocket motors. The missle-destruction area is underlain by a thin alluvial aquifer that is hydraulically connected to the alluvial aquifer of the Arkansas River valley. The missle-disposal area, the landfill, overlies saturated terrace deposit upgradient from the Arkansas River.

OBJECTIVE: Samples of ground water from the aquifers underlying the burn area and landfill need to be collected for chemical analyses. Hydrologic data are needed to evaluate depth to bedrock, saturated thickness, the configuration of the water table, and hydraulic characteristics of the aquifer beneath the landfill.

APPROACH: Test holes will be drilled, monitor wells constructed and developed, and dedicated sampling systems installed at both the burn area and the landfill. Split-spoon samples of subsurface materials will be collected at the burn area. Ground-water samples will be collected from both areas for analysis. Maps will be prepared showing the depth to bedrock, saturated thickness, and water-table configuration at the landfili.

PLANS FOR FY 89: Monitor wells and dedicated sampling systems will-be installed at the burn area and landfill. Subsurface geologic materials and ground-water samples from the burn area and ground-water samples from the landfill will be collected for chemical analyses. Maps showing depth to bedrock, saturated thickness, and water-table configuration for the landfill will be prepared and presented in an open-file report. 
PROJECT TITLE: Conjunctive Water Use and Canal-Seepage Losses in an Extensive Irrigation System, Southeastern Colorado

PROJECT NUMBER: $\quad$ C0-89-238

STUDY LOCATION: $\quad$ Southeastern Colorado, Arkansas

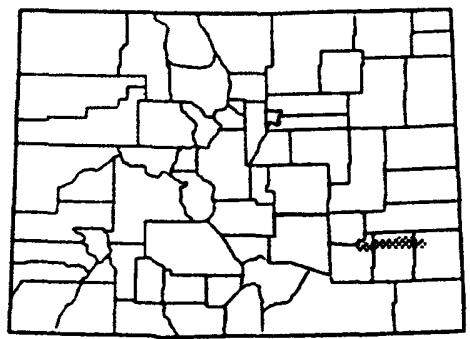

River between LaJunta and Lamar, Colorado

COOPERATING AGENCY: Bent County Board of County Commissioners

PROJECT CHIEF AND OFFICE:

Russell G. Dash, Subdistrict Office, Pueblo

PROJECT DURATION: $\quad$ August 1988 to October 1992

PROBLEM: Land overlying the alluvium of the Arkansas River in southeastern Colorado has been extensively irrigated for more than a century. Rapid changes in the sources and patterns of water use occurred following the completion of the Fryingpan-Arkansas Project by the U.S. Bureau of Reclamation during the 1970's. In addition to providing transmountain water to supplement native surface water, substantial upstream reservoir storage was added that provided a new dimension to irrigation along the Arkansas River. Estimates of water use from hydrologic studies conducted by the U.S. Geological Survey during the 1960's and early 1970's no longer may be valid. Quantification of present-day water use for lands under irrigation by the Fort Lyon Canal, the largest canal system in southeastern Colorado, would enable better present-day and future management of water resources in the area.

OBJECTIVE: The objective of the study is to prepare a water budget by estimating the following for lands irrigated by the Fort Lyon Canal: (1) Use of surface-water resources, (2) use of ground-water resources, (3) Canal-seepage losses, and (4) areal crop consumptive use.

APPROACH: Surface-water use will be estimated from analysis of diversion records for the canal and laterals that make up the irrigation system. Ground-water use will be estimated from a network of observation wells and a network of 30 irrigation wells equipped with vibration timers. Diaries of pumping durations maintained by selected irrigators, records of electrical-power consumption, and periodic discharge measurements will be used to estimate ground-water use for wells not in the network. Canal-seepage losses will be estimated from a combination of instantaneous discharge measurements and flow volumes at gaging stations and lateral diversions along the canal. The estimate of water use, changes in ground-water storage, and quantity of tail water will be used to estimate areal crop consumptive use for each of the five irrigation divisions in the Fort Lyon system.

PROGRESS: Project activities initiated in 1988 included installation and operation of four surface-water gaging stations and collection of daily diversion records at the canal laterals. A field reconnaissance of the current condition of the 357 canal laterals was completed and the information entered into a computerized data base. 
PLANS FOR FY 89: Meetings with canal personnel will be held to discuss system operation and to review surface-water data-collection activities. Additional surface-water stations will be installed based on further review of the data-collection network. A gain-loss investigation of the canal and tail-water measurements will be made during summer 1989. A ground-water-level monitoring network will be established prior to the start of the 1989 irrigation season. Vibration timers will be installed on 30 irrigation wells to estimate ground-water use, and additional wells with electrical power meters will be selected and calibrated for estimation of ground-water use in areas not represented adequately by the vibration-timer network. 
PROJECT TITLE: $\quad$ Evaluation of Trends in Water Quality of the Widefield Aquifer, Southwestern El Paso County, Colorado

PROJECT NUMBER: $\quad$ CO-89-239

STUDY LOCATION: $\quad$ Southwest El Paso County, Colorado

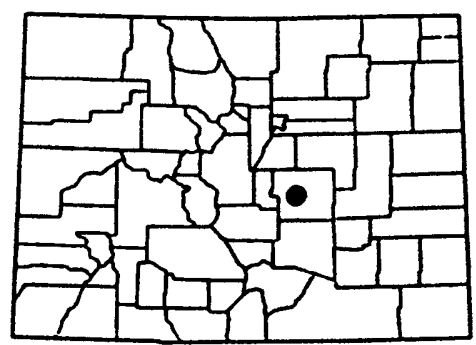

COOPERATING AGENCY: City of Colorado Springs Department of Utilities

PROJECT CHIEF AND OFFICE :

Michael E. Lewis, Subdistrict Office, Pueblo

PROJECT DURATION: November 1988 to September 1990

PROBLEM: Elevated concentrations of nitrate in the Widefield aquifer, which serves as a municipal water supply for several communities, have led to a need for evaluation of temporal trends in concentrations of nitrate and other constituents in water produced from the Widefield aquifer.

OBJECTIVE: Evaluate temporal trends in the concentrations of nitrate, chloride, and specific conductance from the Widefield aquifer, evaluate relations between concentrations of nitrate, chloride, and specific conductance of water from the Widefield aquifer and other hydrologic variables that may affect the concentrations of these constituents, and evaluate the existing monitoring network for the Widefield aquifer relative to its ability for early detection of changes in water quality in the aquifer.

APPROACH: Compile and evaluate water-quality data and data for other hydrologic variables that may be related to concentrations of nitrate, chloride, and specific conductance of water from the Widefield aquifer. Employ parametric or nonparametric statistical techniques or both for evaluating time trends in concentrations of nitrate plus nitrite, chloride, and specific conductance.

PLANS FOR FY 89: Water-quality temporal trends and relations between water quality and other hydrologic variables will be evaluated. The existing water-quality monitoring network will be evaluated for adequacy in the early detection of changes in the aquifer water quality. If necessary, modifications in the monitoring network will be proposed. 
PROJECT TITLE:

PROJECT NUMBER:

STUDY LOCATION:

COOPERATING AGENCY:
Hillslope Hydrology and Sediment Production at Reclaimed Surface-Coal Mines, Northwestern Colorado

$$
\text { C0-89-240 }
$$

Northwestern Colorado

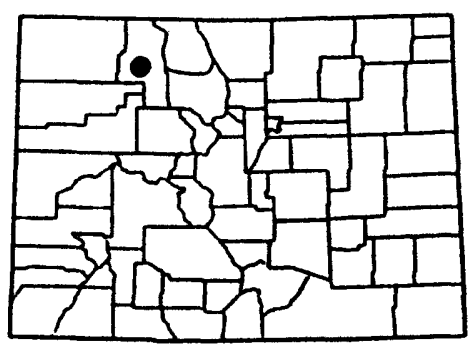

Colorado Department of Natural Resources, Division of Mined Land Reclamation

PROJECT CHIEF AND OFFICE:

John G. Elliott, District Office, Denver

PROJECT DURATION: November 1988 to September 1991

PROBLEM: Surface-coal mining and reclamation activities have increased the erodibility and the quantity of surface runoff in large areas of northwestern Colorado. These changes have resulted in accelerated erosion in many recently reclaimed areas. A previous study by J.G. Elliott (Project Co 85-201) identified statistically significant relations between several geomorphic variables and the degree of erosion on reclaimed hillslopes and valley floors. These relations may be useful reclamation planning tools, but they do not reveal the underlying hydrologic processes that cause hillslope rill erosion

OBJECTIVES: (1) Identify hillslope-hydrologic processes (snow accumulation and melting patterns, soil-water accumulation and distribution, surfacewater accumulation and runoff) active on reclaimed coal-spoil hillslopes; (2) Determine seasonal erosion or deposition of topsoil on selected reclaimed hillslopes and estimate the long-term net topsoil loss; and (3) Identify functional or predictive relations between rill erosion, hillslope hydrology, and other significant variables.

APPROACH: Surface water (snowpack and rainfall) and soil water (unsaturated zone) data will be collected from two recently reclaimed hillslopes. Precipitation on the hillslopes will be measured during the study by analysis of snow surveys and rainfall data. Rain gages with recording equipment and snow-survey courses have been established on both study hillslopes. Soil-water content will be measured several times during the study by neutron-probe measurements and the time-domain reflectometry method. Topsoil infiltration characteristics will be identified with double-capped infiltrometer tests.

Throughflow will be tested with an experiment using several paired soil-water access tubes located on a variety of hillslope gradients and topographies. Topographic effects on surface-water accumulation, soilwater content, and throughflow will be assessed by an analysis of data collected from soil-water access tubes installed on a variety of hillslope gradients and profiles (convex, straight, and concave). Aspect effects will be assessed by comparing data collected from two hillslopes of different aspect (west-northwest and south-southeast). 
Hillslope sediment production will be studied on the two reclaimed hillslopes where hydrologic data will be collected. The hillslopes will be subdivided into smaller study areas that have a variety of gradients, aspects, and other characteristics representative of the entire hillslope. Each study area on the hillslope will be monumented and surveyed, and rills in these study areas will be mapped in detail before the snowpack accumulates, after the snowpack melts, and after large rain events. Net topsoil loss by rill erosion and sheet erosion (or net aggradation by deposition) will be determined for each study area from differences in the surveyed topsoil surface profiles and rill maps. The net topsoil loss (or aggradation) will be extrapolated to the entire study hillslope.

Tests will be made to identify statistically significant relations between sediment-production data (rill density, rill volume, and sheet erosion), hydrologic data (snow distribution, antecedent soil water, and distribution and movement of soil water), and other data (hillslope gradient, length, and profile, aspect, topsoil texture and infiltration rate, age of reclamation, vegetation cover). The statistical methods used will include multiple-regression analysis, analysis of covariance, and discriminant-function analysis.

PROGRESS: Installation of several surface-water access tubes (SWATs) began in October and was completed in early November. Three sets of neutron probe measurements have been made, and these soil-water data have been plotted. Soil-water contents increased between November and December at all SWATs; however, little snow had accumulated by mid-December. Late initiation of the project and early snowfall prevented installation of the time-domain reflectometry (TDR) probes and survey of the rill-study test plots.

PLANS FOR FY 89: Monthly measurements of soil-water content and snowpack will continue in the second quarter of FY 89 . The frequency of measurements will increase when spring melting begins. TDR equipment will be procured, and consultation will be made with other project chiefs (von Guerard, Leavesley) who are using TDR. The TDR equipment will be installed and rill surveys will be completed in the spring. 


\title{
AVAILABILITY OF COLORADO DISTRICT REPORTS
}

Published reports are announced in the U.S. Geological Survey monthly catalog "New Publications of the Geological Survey." This monthly catalog is a list of (1) books and maps that were published by the U.S. Geological Survey during the previous month and (2) articles by U.S. Geological Survey personnel in non-Geological Survey journals and books. The monthly catalog is available free of charge from U.S. Geological Survey, 582 National Center, Reston, VA 22092. A yearly composite catalog is available from U.S. Geological Survey, Books and Open-File Reports Section, Box 25425, Federal Center, Denver, Co 80225-0425 (cost varies by year).

U.S. GEOLOGICAL SURVEY: OPEN-FILE REPORTS--are available only through:

\author{
U.S. Geological Survey \\ Books and Open-File Reports Section \\ Federal Center \\ Box 25425 \\ Denver, CO 80225-0425 \\ [Telephone: (303) 236-7476]
}

When ordering, please use the open-file report number and full title.

U.S. GEOLOGICAL SURVEY: WATER-RESOURCES INVESTIGATIONS REPORTS--MOst are available through Books and Open-File Reports Section (same address as above). When ordering, please use the water-resources investigations report number and full title.

U.S. GEOLOGICAL SURVEY: WATER-RESOURCES DATA REPORTS for Colorado and for the 1987 and 1988 water years are available only from:

\author{
National Technical Information Service \\ U.S. Department of Commerce \\ Springfield, VA 22161
}

When ordering, please use the NTIS number.

Selected water-resources investigations reports are available only from the National Technical Information Service (same address as above). When ordering, please use the NTIS number.

U.S. GEOLOGICAL SURVEY: PROFESSIONAL PAPERS, BULLETINS, WATER-SUPPLY PAPERS; TECHNIQUES OF WATER-RESOURCES INVESTIGATIONS, CIRCULARS--are available from:

U.S. Geological Survey

Books and Open-File Reports Section

Federal Center

Box 25425

Denver, CO 80225-0425

[Telephone: (303) 236-7476] 
U.S. GEOLOGICAL SURVEY: WATER-RESOURCES INVESTIGATIONS OPEN-FILE REPORTS are listed in the U.S. Geological Survey monthly periodical "New Publications of the Geological Survey" in section "Reports Available Only Through Certain Geological Survey Field Offices," and are available only from:

District Chief

U.S. Geological Survey

Water Resources Division,

Colorado District

Room H-2104, Bldg. 53

Denver Federal Center

Telephone: (303) 236-4882

Mailing Address:

U.S. Geological Survey

P. O. Box 25046, Mail Stop 415

Denver Federal Center

Denver, Colorado 80225-0046

U.S. GEOLOGICAL SURVEY: MAPS--may be purchased by mail at:

Distribution Branch

U.S. Geological Survey

P. O. Box 25286, Denver Federal Center

Denver, Colorado 80225-0286

or over the counter at:

Earth Science Information Center

U.S. Geological Survey

Room 169, Federal Building

1961 Stout Street

Denver, Colorado 80202

Telephone: (303) 844-4169

Distribution Branch

U.S. Geological Survey

Building 810, Entrance E7

Denver Federal Center

Denver, Colorado 80225

Telephone: (303) 236-7477 
REPORTS PUBLISHED OR RELEASED DURING FISCAL YEARS 1987, 1988, AND 1989

Water-Resources Data Reports

[Reports available from U.S. Geological Survey, Books and Open-File Reports Section, Box 25425, Denver Federal Center, Denver, CO 80225-0425, except as indicated]

1. Gaggiani, N.G., 1989, Indexes of hydrologic data from selected coalmining areas in northwestern Colorado: U.S. Geological Survey OpenFile Report 88-347, $30 \mathrm{p}$.

2. Geldon, A.L., 1989, Hydrologic data for Paleozoic rocks in the Upper Colorado River Basin, Colorado, Utah, Wyoming, and Arizona: U.S. Geological Survey Open-File Report 89-59, 219 p.

3. Kuhn, Gerhard, and Ortiz, R.F., 1989, Selected hydrologic data for Fountain Creek and Monument Creek basins, east-central Colorado: U.S. Geological Survey Open-File Report 88-705, 106 p.

4. Reed, R.L., 1988, Ground-water hydrographs, 1970-87, and water-level data, 1986-87, for the northern high plains of Colorado: U.S. Geological Survey Open-File Report 88-178, 349 p.

5. Stewart, J.M., compiler, 1987, Summary of water-resources activities of the U.S. Geological Survey in Colorado--Fiscal year 1987: U.S. Geological Survey Open-File Report 87-388, $65 \mathrm{p}$.

6. U.S. Geological Survey, 1988, Water resources data for Colorado--Water year 1987, Volume 1, Missouri River basin, Arkansas River basin, and Rio Grande basin: U.S. Geological Survey Water-Data Report C0-87-1; available only from the U.S. Department of Commerce, National Technical Information Service, Springfield, VA 22161, as PB88243043, 409 p.

7. 1988, Water resources data for Colorado--Water year 1987, Volume 2, Colorado River basin: U.S. Geological Survey Water-Data Report CO-87-2; available only from the U.S. Department of Commerce, National Technical Information Service, Springfield, VA 22161, as PB88-243050, $394 \mathrm{p}$.

8. 1989, Water resources data for Colorado--Water year 1988, Volume 1, Missouri River basin, Arkansas River basin, and Rio Grande basin: U.S. Geological Survey Water-Data Report C0-88-1; available only from the U.S. Department of Commerce, National Technical Information Service, Springfield, VA 22161, as PB89-190433, $423 \mathrm{p}$.

9. 1989, Water resources data for Colorado--Water year 1988, Volume 2, Colorado River basin: U.S. Geological Survey Water-Data Report CO-88-2; available only from the U.S. Department of Commerce, National Technical Information Service, Springfield, VA 22161, as PB89-190441, $381 \mathrm{p}$. 


\section{Water-Resources Interpretive Reports}

1. Banta, E.R., 1989, Hydrologic effects of pumpage from the Denver basin bedrock aquifers of northern El Paso County, Colorado: U.S. Geological Survey Water-Resources Investigations Report 88-4033, $84 \mathrm{p}$.

2. Britton, L.J., and Greeson, P.E., editors, 1989, Methods for collection and analysis of aquatic biological and microbiological samples: U.S. Geological Survey Techniques of Water-Resources Investigations of the United States Geological Survey, Book 5, Chapter A4, 363 p.

3. Buckles, D.R., and Watts, K.R., 1988, Geohydrology, water quality, and preliminary simulations of ground-water flow of the alluvial aquifer in the upper Black Squirrel Creek basin, El Paso County, Colorado: U.S. Geological Survey Water-Resources Investigations Report 88-4017, $49 \mathrm{p}$.

4. Burns, A.W., 1988, Computer-program documentation of an interactiveaccounting model to simulate streamflow, water quality, and watersupply operations in a river basin: U.S. Geological Survey Water-Resources Investigations Report 88-4012, $241 \mathrm{p}$.

5. 1989, Calibration and use of an interactive-accounting model to simulate dissolved solids, streamflow, and water-supply operations in the Arkansas River basin, Colorado: U.S. Geological Survey Water-Resources Investigations Report 88-4214, $116 \mathrm{p}$.

6. Busby, J.F., Kimball, B.A., Downey, J.S., and Peters, K.D., in press, Geochemistry of ground water in aquifers and confining units of the Northern Great Plains in parts of Montana, North Dakota, South Dakota, and Wyoming: U.S. Geological Survey Professional Paper 1402-F.

7. Butler, D.L., in press, Estimated water-quality conditions and potential downstream channel effects of the proposed Rock Creek and Wolford Mountain Reservoirs, north-central Colorado: U.S. Geological Survey Water-Resources Investigations Report 89-4177.

8. Cain, Doug, Helse I, D.R., and Ragone, S.E., 1989, Preliminary evaluations of regional ground-water quality in relation to land use: Ground Water, March-April 1989, v. 27, no. 2, p. 230-244.

9. Driver, N.E., in press, Variables that affect urban storm-runoff quality and quantity, in International Association of Hydrologic Sciences Third Scientific Assembly, Baltimore, Md., 1989, Proceedings.

10. Driver, N.E., and Tasker, G.D., 1988, Techniques for estimation of stormrunoff loads, volumes and selected constituent concentrations- in urban watersheds in the United States: U.S. Geological Survey OpenFile Report 88-191, 80 p. (pending publication as U.S. Geological Survey Water-Supply Paper 2363).

11. Driver, N.E., and Troutman, B.M., 1989, Regression models for estimating urban storm-runoff quality and quantity in the United States: Journal of Hydrology (in press).

12. Eckhardt, D.W., and Litke, D.W., 1988, Estimation of reservoir surface areas using satellite imagery, upper Gunnison River basin, Colorado, in American Water Resources Association Symposium on Water Use Data for Water Resources Management, Tucson, Ariz., 1988, Proceedings: Bethesda, Md., American Water Resources Association, p. 691-702.

13. Edelmann, Patrick, 1989, Reconnaissance of water quality of Pueblo Reservoir, Colorado--May through December 1985: U.S. Geological Survey Water-Resources Investigations Report 88-4118, 53 p. 
Water-Resources Interpretive Reports--Continued

14. Edelmann, Patrick, in press, Water quality of Fountain and Monument Creeks, south-central Colorado, with emphasis on relation of water quality to stream classifications: U.S. Geological Survey WaterResources Investigations Report 88-4132.

15. Elliott, J.G., 1988, Regionalization of mean annual suspended-sediment loads in streams, central, northwestern, and southwestern Colorado: U.S. Geological Survey Water-Resources Investigations Report 87-4193, $24 \mathrm{p}$.

16. _ in press, A geomorphically determined valley-erosion threshold for reclaimed surface-mined drainage basins, northwestern Colorado, in American Water Resources Association "Headwaters Hydrology" Symposium, Missoula, Mont., 1989, Proceedings: Bethesda, Md., American Water Resources Association.

17. Geldon, A.L., 1988a, Hydrostratigraphic characterization of Paleozoic formations in the Upper Colorado River Basin, Arizona, Colorado, New Mexico, Utah, and Wyoming, in McLean, J.S., and Johnson, A.I., eds., Regional aquifer systems of the United States--Aquifers of the western mountain area [Annual American Water Resources Association Conference and Symposium, 23d, Salt Lake City, 1987, Proceedings]: Bethesda, Md. , American Water Resources Association Monograph Series no. 14 , p. 135-159.

18. 1988b, Porosity and permeability of the Paleozoic rocks in the Upper Colorado River Basin, Arizona, Colorado, New Mexico, Utah, and Wyoming, in McLean, J.S., and Johnson, A.I., eds., Regional aquifer systems of the United States--Aquifers of the western mountain area [Annual American Water Resources Association Conference and Symposium, 23d, Salt Lake City, 1987, Proceedings]: Bethesda, Md., American Water Resources Association Monograph Series no. 14, p. $171-190$.

19. 1989, Hydrogeology of the Leadville Limestone and other Paleozoic rocks in northwestern Colorado, with results of aquifer tests at Glenwood Springs: U.S. Geological Survey Water-Resources Investigations Report 87-4195, $96 \mathrm{p}$.

20. Hurr, R.T., and Litke, D.W., 1989, Estimating pumping time and groundwater withdrawals using energy-consumption data: U.S. Geological Survey Water-Resources Investigations Report 89-4107, 58 p.

21. Hearne, G.A., and Dewey, J.D., 1988, Hydrologic analysis of the Rio Grande basin north of Embudo, New Mexico, Colorado and New Mexico: U.S. Geological Survey Water-Resources Investigations Report 86-4113, $244 \mathrm{p}$.

22. Jarrett, R.D., 1988, Hydroclimatic data errors and their effects on the perception of climate change, in Monitoring Climate for the Effects of Increasing Greenhouse Gas Concentration, 1987, Pingree Park, Colo., Proceedings: Fort Collins, Colorado State University, p. $149-158$.

23. _ in press, Hydrologic and hydraulic research in mountain rivers, in International Symposium on Hydrology of Mountain Areas, Strbske Pleso, Czechoslovakia, 1988, Proceedings.

24. Jarrett, R.D., and Crow, L.W., 1988, Experimental Marvin windshield effects on precipitation records in Leadville, Colorado: American Water Resources Association Water Resources Bulletin paper no. 87110 , v. 24 , no. 3 , p. 615-626. 


\section{Water-Resources Interpretive Reports--Continued}

25. Kimball, B.A., 1988, Geochemistry of water associated with the Navajo Sandstone aquifer, San Rafael Swell area, Utah, in McLean, J.S., and Johnson, A.I., eds., Regional aquifer systems of the United States-Aquifers of the western mountain area [Annual American Water Resources Association Conference and Symposium, 23d, Salt Lake City, 1987, Proceedings]: Bethesda, Md., American Water Resources Association Monograph Series no. 14, p. 121-133.

26. Kimball, B.A., Bencala, K.E., and McKnight, D.M., 1989, Research on metals in acid mine drainage in the Leadville, Colorado, area, in Mallard, G.E., and Ragone, S.E., eds., U.S. Geological Survey Toxic Substances Hydrology Program--Proceedings of the Technical Meeting, Phoenix, Arizona, September 26-30, 1988: U.S. Geological Survey Water-Resources Investigations Report 88-4220, p. 65-70.

27. Kimball, B.A., and McKnight, D.M., 1989, Metal Partitioning and photoreduction of iron in filtrates of acid streamwater, St. Kevin Gulch, Leadville, Colorado, in Mallard, G.E., and Ragone, S.E., eds., U.S. Geological Survey Toxic Substances Hydrology Program--Proceedings of the Technical Meeting, Phoenix, Arizona, September 26-30, 1988: U.S. Geological Survey Water-Resources Investigations Report 88-4220, p. 93-100.

28. Kimball, B.A., and Wetherbee, G.A., 1989, Instream chemical reactions after acidic mine water enters a neutral stream near Leadville, Colorado, in Mallard, G.E., and Ragone, S.E., eds., U.S. Geological Survey Toxic Substances Hydrology Program--Proceedings of the Technical Meeting, Phoenix, Arizona, September 26-30, 1988: U.S. Geological Survey Water-Resources Investigations Report 88-4220, p. 71-79.

29. Kuhn, Gerhard, 1988a, Methods to determine transit losses for return flows of transmountain water in Fountain Creek between Colorado Springs and the Arkansas River, Colorado: U.S. Geological Survey Water-Resources Investigations Report 87-4119, $183 \mathrm{p}$.

30. 1988b, Application of the U.S. Geological Survey's precipitationrunoff modeling system to Williams Draw and Bush Draw basins, Jackson County, Colorado: U.S. Geological Survey Water-Resources Investigations Report 88-4013, $40 \mathrm{p}$.

31. Leonard, G.J., and Watts, K.R., 1989, Hydrogeology and simulated effects of ground-water development on an unconfined aquifer in the Closed Basin Division, San Luis Valley, Colorado: U.S. Geological Survey Water-Resources Investigations Report 87-4284, $42 \mathrm{p}$.

32. Liebermann, T.D., Mueller, D.K., Kircher, J.E., and Choquette, A.F., 1988, Characteristics and trends of streamfiow and dissolved solids in the Upper Colorado River Basin, Arizona, Colorado, New Mexico, Utah, and Wyoming: U.S. Geological Survey Open-File Report 87-568, 99 p. (pending publication as U.S. Geological Survey Water-Supply Paper 2358).

33. Litke, D.W., and Appel, C.L., 1989, Estimated use of water in Colorado, 1985: U.S. Geological Survey Water-Resources Investigations Report 88-4101, $157 \mathrm{p}$.

34. Litke, D.W., and Evans, N.A., in press, Colorado--Water supply and demand, in National Water Summary 1987: U.S. Geological Survey Water-Supply Paper 2350. 


\section{Water-Resources Interpretive Reports--Continued}

35. Livingston, R.K., 1988, Determining transit losses for water deliveries by use of stream-aquifer models, in Proceedings on Planning Now for Irrigation and Drainage for the 21st Century, Irrigation and Drainage Division, American Society of Civil Engineers, Lincoln, Nebr., July 18-21, 1988: New York, American Society of Civil Engineers, p. $165-175$.

36. McKnight, D.M., Kimball, B.A., and Bencala, K.E., 1988, Iron photoreduction and oxidation in acidic mountain streams: Science, v. 240, p. 637-640.

37. Mueller, D.K., and Liebermann, T.D., 1988, Extension of streamflow and dissolved-solids records at selected sites in the Colorado River basin, Arizona, California, Colorado, Nevada, New Mexico, Utah, and Wyoming, 1940-83: U.S. Geological Survey Water-Resources Investigations Report 87-4203, 74 p.

38. Mueller, D.K., and Osen, L.L., 1988, Estimation of natural dissolvedsolids discharge in the Upper Colorado River Basin, western United States: U.S. Geological Survey Water-Resources Investigations Report 87-4069, 62 p.

39. Nelson, G.A., Hurr, R.T., and Moore, J.E., 1989a, Hydrogeologic characteristics of the valley-fill aquifer in the Arkansas River valley, Crowley and Otero Counties, Colorado: U.S. Geological Survey OpenFile Report $89-255$, scale $1: 62,500,3$ sheets.

40. 1989b, Hydrogeologic characteristics of the valley-fill aquifer in the Arkansas River valley, Prowers County, Colorado: U.S. Geological Survey Open-File Report 89-254, scale $1: 62,500,3$ sheets.

41. 1989c, Hydrogeologic characteristics of the valley-fill aquifer in the Arkansas River valley, Pueblo County, Colorado: U.S. Geological Survey Open-File Report 89-256, scale 1:62,500, 3 sheets.

42. Norris, J.M., Hren, Janet, Myers, Donna, Chaney, T.H., and OblingerChildress, C.J., in press, Water-quality data-collection activities in Colorado and Ohio: Phase III--evaluation of existing data for use in assessing regional water-quality conditions and trends: U.S. Geological Survey Open-File Report 89-391.

43. Parker, R.S., in press, Characterization of water quality for streams in the southern Yampa River basin, northwestern Colorado: U.S. Geological Survey Water-Resources Investigations Report 88-4204.

44. in press, Uncertainties in defining the suspended-sediment budget for large drainage basins, in International Association of Hydrological Sciences Symposium on Sediment Budgets, Porto Alegre, Brazil, 1988, Proceedings: Oxfordshire, UK, International Associ-: ation of Hydrological Sciences.

45. Parker, R.S., and Norris, J.M., 1989, Simulation of streamflow in small drainage basins in the southern Yampa River basin, Colorado: U.S. Geological Survey Water-Resources Investigations Report 88-4071, $47 \mathrm{p}$.

46. Parker, R.S., and Troutman, B.M., in press, Frequency distribution for suspended-sediment loads: Water Resources Research.

47. Ruddy, B.C., in press, Use of a hydraulic potentiomanometer to determine ground-water gradients in a wetland, Colorado, in American Water Resources Association "Headwaters Hydrology" Symposium, Missoula, Mont., 1989, Proceedings: Bethesda, Md., American Water Resources Association. 


\section{Water-Resources Interpretive Reports--Continued}

48. Ruddy, B.C., and Britton, L.J., 1989, Traveltime and reaeration of selected streams in the North Platte and Yampa River basins, Colorado: U.S. Geological Survey Water-Resources Investigations Report 88-4205, $58 \mathrm{p}$.

49. Tasker, G.D., and Driver, N.E., 1988, Nationwide regression models for predicting urban runoff water quality at unmonitored sites: Water Resources Bulletin, v. 24, no. 5, p. 1091-1101.

50. Taylor, 0.J., compiler, 1987, 0il shale, water resources, and valuable minerals of the Piceance basin, Colorado--The challenge and choices of development: U.S. Geological Survey Professional Paper 1310, $143 \mathrm{p}$.

51. 1988, Predicted effects of underground mine flooding at tract $c-b$ in Piceance basin, northwestern Colorado: U.S. Geological Survey Water-Resources Investigations Report 87-4189, 16 p.

52. Turk, J.T., and Spahr, N.E., 1989a, Chemistry of lakes in the Rocky Mountains, conterminous United States, in Advances in Environmental Sciences--Acid Precipitation [series]: New York, Springer-Verlag (in press).

53. 1989b, Controls of $\mathrm{SO}_{4}^{-2}$ and $\mathrm{CL}^{-}$in Rocky Mountain Lakes, in International Mountain Watershed Symposium, South Lake Tahoe, Nev., 1988, Proceedings: Lake Tahoe, Nev., American Geophysical Union (in press).

54. 1989c, Rocky Mountains: Controls on lake chemistry, chapter in Regional case studies in acid rain [book]: (in press).

55. Von Guerard, Paul, in press, Effects of land use on sediment yield, southeastern Colorado, in American Water Resources Association "Headwaters Hydrology" Symposium, Missoula, Mont., 1989, Proceedings: Bethesda, Md., American Water Resources Association.

56. 1989a, Suspended sediment and sediment-source areas in the Fountain Creek drainage bas in upstream from Widefield, southeastern Colorado: U.S. Geological Survey Water-Resources Investigations Report $88-4136,36 \mathrm{p}$.

57. 1989b, Sediment-transport characteristics and effects of sediment transport on benthic invertebrates in the Fountain Creek drainage bas in upstream from Widefield, southeastern Colorado, 1985-88: U.S. Geological Survey Water-Resources Investigations Report 89-4161, 225 p.

58. Von Guerard, Paul, Abbott, P.0., and Nickless, R.C., 1987, Hydrology of the U.S. Army Pinon Canyon maneuver site, Las Animas County, Colorado: U.S. Geological Survey Water-Resources Investigations Report 87-4227, $117 \mathrm{p}$.

59. Watts, K.R., and Ortiz, R.F., Geohydrology and ground-water quality at the Pueblo Depot Activity Landfill near Pueblo, Colorado: U.S. Geological Survey Water-Resources Investigations Report 89-4143, 75 p.

60. Weiss, Emanue1, 1987, Ground-water flow in the Navajo Sandstone in parts of Emery, Grand, Carbon, Wayne, Garfield, and Kane Counties, southeast Utah: U.S. Geological Survey Water-Resources Investigations Report 86-4012, 41 p.

61. in press, Differences in hydraulic head calculated for aquifers represented by folds and flat surfaces: Water Resources Research.

62. in press, Evaluating the hydraulic effects of aquifer folds, in Encyclopedia of Fluid Mechanics. 


\section{Water-Resources Interpretive Reports--Continued}

63. Wetherbee, G.A., and Van Liew, W.P., 1988, Geophysically determined porosity of Paleozoic rocks in the Upper Colorado River Basin, in McLean, J.S., and Johnson, A.I., eds., Regional aquifer systems of the United States--Aquifers of the western mountain area [Annual American Water Resources Association Conference and Symposium, 23d, Salt Lake City, 1987, Proceedings]: Bethesda, Md., American Water Resources Association Monograph Series no. 14, p. 161-169.

64. Williams, R.S., Jr., and Driver, N.E., 1987, Ground water study 10, in Ground-water information manual--Coal mine permit applications, Volume II: U.S. Office of Surface Mining Reclamation and Enforcement, p. 337-364.

65. Williams, R.S., Jr., and Hammond, S.E., 1988, Soil-water hydrology and geochemistry of a coal spoil at a reclaimed surface mine in Routt County, Colorado: U.S. Geological Survey Water-Resources Investigations Report 86-4350, 100 p.

66. in press, Selected water-quality characteristics and flow of ground water in the San Luis basin, including the Conejos River subbasin, Colorado and New Mexico: U.S. Geological Survey Water-Resources Investigations Report 89-4040, 43 p.

\section{DEPOSITORIES}

Reports are available for examination at the following U.S. Geological Survey depositories:

Colorado District Office, Water Resources Division, Room H-2101, Building 53 (mailing address: Box 25046, Mail Stop 415), Denver Federal Center, Denver, CO 80225-0046.

Earth Science Information Center, Room 169 Federal Building, 1961 Stout Street, Denver, CO 80202.

Library, Room C2002, 2d Floor, Building 20, Denver Federal Center, Denver, Colo. (mailing address: Box 25046, Mail Stop 914, Denver Federal Center, Denver, CO 80225-0046).

Library, Room 4A100, 950 National Center, 12201 Sunrise Valley Drive, Reston, VA 22092.

Library, 345 Middlefield Road, (mailing address: Mail Stop 55, Building 5), Menlo Park, CA 94025.

U.S. Department of the Interior, National Resources Library, Gifts and Exchange Section, 18th and C Streets NW, Washington, DC 20240. 
PROJECTS COMPLETED EXCEPT FOR REPORTS DURING

FISCAL YEAR 1989

\begin{tabular}{cll} 
Project number & \multicolumn{1}{c}{ Project title } & \multicolumn{1}{c}{ Project Chief } \\
C0-143 & $\begin{array}{l}\text { Upper Black Squirrel Creek Basin } \\
\text { Ground Water }\end{array}$ & Kenneth R. Watts \\
C0-183 & $\begin{array}{l}\text { Preliminary Assessment of Methods } \\
\text { for Determination of Evaporation } \\
\text { Components by Water Resources } \\
\text { Council (WRC) Subregions }\end{array}$ & Barbara C. Ruddy \\
C0-186 & $\begin{array}{l}\text { Water Quality of Kenney Reservoir } \\
\text { C0-201 }\end{array}$ & $\begin{array}{l}\text { Geomorphic Stability of Reclaimed } \\
\text { Land Surface in the Green River } \\
\text { Coal-Resource Region }\end{array}$ \\
C0-203 & $\begin{array}{l}\text { Impacts of Coal-Mine Development } \\
\text { on Ground-Water Resources in the }\end{array}$ & John G. Elliott \\
Twentymile Park Area, Northwest \\
Colorado
\end{tabular}

